\title{
The Role of Phenolic Compounds in the Fight against Cancer - A Review
}

\author{
Márcio Carocho and Isabel C.F.R. Ferreira ${ }^{*}$
}

Mountain Research Center (ESA), Polytechnic Institute of Bragança, Apartado 1172, 5301-855 Bragança, Portugal

\begin{abstract}
Cancer is a worldwide scourge; it's the leading cause of death in developed countries and is increasing in developing countries. Mankind has been trying with effort to find better and cheaper treatments with fewer side effects, to reduce the incidence of the disease and its consequent mortality. For many years, phenolic compounds have been intensely studied for their antitumor, proapoptotic and antiangiogenic effects. In recent years, the usage of these compounds has increased considerably.

This manuscript intends to structurally characterize the different phenolic compounds (flavonoids, hydroxycinnamates, hydroxybenzoates, coumarins, xanthones, chalcones, stilbenes, lignins and lignans) and their metabolic pathways as well as review the most important results regarding these compounds and their derivatives in cancer treatment and prevention both in tumor cell lines in vitro, in murine models in vivo and finally some results regarding human trials.
\end{abstract}

Keywords: Animal models, anticancer, antitumoral, cell lines, clinical trials, phenolic compounds

\section{INTRODUCTION}

Cancer is a worldwide burden that causes millions of deaths each year. In fact, it is the leading cause of death in developed countries, slaughtering 7.6 millions of lives in 2008. The developing countries have begun to register increasing cases of cancer due to cancer-causing behaviors like smoking and unbalanced diets. Of the 7.6 million deaths in 2008, 64\% were in developing countries [1]. The economic impact on the prophylaxis and treatment of this disease is monumental, reaching in 2002, over 60 million dollars in the United States alone [2]. The social and cultural implications are harder to calculate but also deserve a profound and adequate reflection as they afflict millions of citizens around the world. Despite the giant leap that anticancer treatments have undergone in the past decades it is still imperative to diminish the mortality and suffering of patients and reduce the costs of treatments. The world needs faster, more efficient and specific treatments for the different types of cancer, and one of the main drawbacks is drug resistance. This resistance may emerge from a variety of reasons, including alteration in the binding site of the target, metabolism and export mechanisms via genetic or epigenetic alterations [3]. The quest to find these efficient drugs is everlasting and worldwide research is growing every day.

Since ancient times, plants have been used as remedies to treat different types of illnesses and lesions with satisfying results. Today, more than $60 \%$ of anticancer drugs come from natural compounds or are derived from them, making these bioactive molecules become increasingly interesting for drug companies, even as prototypes of final formulations for anticancer drugs $[4,5]$. It is known that plant extracts can display interesting anticancer effects on cell lines and murine models, yielding higher effects when compared to pure natural or synthetic compounds. Despite this remarkable effect, it is difficult to assess which compounds are interacting with the cancer cells or if this orchestrated effect is due to synergy between various compounds. Another disadvantage of extracts is the difficulty to obtain enough quantity of plants to produce them, while the natural compounds can, in some cases, be synthesized in a laboratory, reducing the need for intense gathering.

*Address correspondence to this author at the Mountain Research Center (ESA), Polytechnic Institute of Bragança, Apartado 1172, 5301-855 Bragança, Portugal; Tel: +351-273-303219; Fax: +351-273-325405;

E-mail: iferreira@ipb.pt

\section{SECONDARY METABOLITES}

For 200 years, modern chemistry has managed to describe the functions of plant primary metabolites as being related to basic functions like cell division and growth, respiration, storage and reproduction. These metabolites comprehend phytosterols, acyl lipids, nucleotides, amino acids and organic acids. Secondary metabolites tend to accumulate in plant tissues; they play an important role in the plants adaptation process, acting as antibiotics, antifungals, antivirals, UV absorbing agents to reduce damage to tissues, signal molecules, allelopathic agents, attractants for pollinators and seed-dispersing animals as well as protecting the plant against herbivores. For mankind, these metabolites are also important for providing dyes, fibers, glues, oils, waxes, flavoring agents, perfumes, insecticides, herbicides and are sources of new natural drugs for many diseases $[6,7]$. The secondary metabolites are usually classified through their biosynthetic pathways, and are divided into three large families: alkaloids, terpenes and steroids, and phenolic compounds [6]. They are mainly found in storage tissues rather than in vegetative ones, due to their high biologic potency [8].

\subsection{Terpenes and Steroids}

Terpenes and steroids are known for their lipophilic properties and their biosynthetic origin through the mevalonate and mevalonate-independent pathways. In terms of structure, they are unsaturated cyclic or linear hydrocarbons with varying degrees of oxygenation. They are subdivided according to the number of five carbon units (isoprene) which are the building blocks of these compounds. It is now known that isoprene occurs naturally but is not involved in the formation of these compounds, rather by isomers of isopentenyl pyrophosphate and dimethylallyl pyrophosphate. Terpenes may vary from monoterpenoids $\left(\mathrm{C}_{10}\right)$ to tertraterpenoids $\left(\mathrm{C}_{40}\right)$, which are forty carbon molecules. Steroids are modified triterpenoids $\left(\mathrm{C}_{30}\right)$ and derive from squalene which is transformed into lanosterol. The basic structure of steroids is the well-known cholesterol molecule, with the typicall four fused cycloalkane rings. Substitutions in the functional groups surrounding the nucleus which is formed by the fused rings, confer a high metabolic activity to steroids, allowing them to be used as hormones, drugs and anti-inflammatory medication [7-11].

\subsection{Alkaloids}

The alkaloids are a diverse group of low molecular weight, nitrogen-containing compounds. They also play a defensive role in 
plants, defending them from herbivores and pathogens. As many as 12000 alkaloids have been used as pharmaceuticals, stimulants, narcotics and poisons since the first alkaloid, morphine, was discovered [7]. Not all alkaloids derive from amino acids and, allowing a division into four groups: a) alkaloids derived from amino acids (ornithine, arginine, lysine, histidine, phenylalanine/ tyrosine, tryptophan, anthranilic acid and nicotinic acid); b) purine alkaloids (xanthine and caffeine); c) aminated terpenes (diterpene aconitine, triterpene solanine); e) polyketide alkaloids (consisting of nitrogen introduced into a polyketide carbon skeleton) [12].

\subsection{Phenolic Compounds}

Phenolic compounds are widely dispersed throughout the plant kingdom representing about 8000 different phenolic structures. As secondary metabolites they also display defensive, growth and development effects. They have at least one aromatic ring with one or more hydroxyl groups attached, being able to range from low molecular weight molecules to large and complex ones. The biosynthesis of phenolic compounds involves the shikimate, phenilpropanoid and flavonoid pathways [7, 13]. Phenolic compounds generally appear as esters and glycosides rather than as free compounds due to the conferred stability of these molecules. This family of compounds is one of the most studied worldwide and innumerous publications report beneficial effects in various aspects of human health and well-being [13-15]. Fig. (1) represents the various groups of molecules within the phenolic compounds family, while Table 1 displays their structure as well as the number of carbons and representative compounds.

\subsubsection{Hydroxybenzoic Acids}

Regarding the Hydroxybenzoic acids group, they are composed of seven carbon molecules with a C6-C1 skeleton and are produced through the shikimate pathway. These compounds are universally distributed in the plant kingdom, being gallic, protocatechuic, vanillic, and syringic acids the four most abundant compounds. Within this group of compounds there is a sub-group, the tannins, which vary greatly from small molecules to large ones. There are two categories of tannins, the hydrolysable and the nonhydrolysable or condensed tannins. The hydrolysable tannins have a central core of polyhydric alcohol such as glucose and hydroxyl groups which can be esterified by gallic acid, while condensed tannins are structurally more complex and are the result of polymerization by some flavonoids [7, 10, 16, 17].

\subsubsection{Hydroxycinammic Acids}

The Hydroxycinnamic acids represent a group of compounds that derive from cinnamic acid through the phenilpropanoid pathway. They display a C6-C3 skeleton of trans-phenyl-3propenoic acid with one or more hydroxyl groups attached to the phenyl moiety, some of which may be methylated. The precursors of this group of compounds are the aminoacids L-phenylalanine and L-tyrosine. Hydroxycinammic acids display a defensive and UV protective effect in plant models. The most abundant compounds within this group are $p$-coumaric, caffeic and ferulic acids [7, 10, $18,19]$.

\subsubsection{Coumarins}

Coumarins derive from phenolic acids and display a benzene ring fused to an oxygen heterocycle. The four most common coumarins are coumarin, umbelliferone, esculetin and scopoletin among the 1000 naturally occurring ones in higher plants. Free coumarins can be found in plants, but most of the simple ones are usually glycated. The major quantities of coumarins are found in roots and seeds, but have also been described in all the different organs of plants [20,21].

\subsubsection{Xanthones}

These compounds occur mostly in higher plant families, namely in the Gentianaceae, Guttiferae, Polygalaceae, Leguminosae, Lythraceae, Moraceae, Loganiaceae, and Rhamnaceae. Structurally they are comprised of heterocyclic compounds, quite similar to flavonoids, with a C6-C1-C6 skeleton. Xanthones are usually classified in 5 major groups: Simple oxygenated xanthones, xanthone glycosides, prenylated and related xanthones, xanthonolignoids and miscellaneous. Their in vitro and in vivo antitumor potential has recently been object of a considerable numbert of studies [22].

\subsubsection{Chalcones}

Chalcones display a C6-C3-C6 skeleton without a heterocyclic $\mathrm{C}$-ring and are intermediates in the formation of all flavonoids. They have an open chain conformation with two aromatic rings joined by a three-carbon $\alpha, \beta$ - unsaturated carbonyl system. Most chalcones are yellow colored and occur mostly in flowers, but can be found in other plant organs. Some occur as glycosides, although most of them are found as free aglycones. They have been reported to have antioxidant, anti-fungal and anti-cancer properties [21, 23].

\subsubsection{Stilbenes}

The members of the stilbene family exhibit a C6-C2-C6 structure and derive from the same biosynthetic pathway as flavonoids. Although small, these compounds are widely distributed throughout the plant kingdom. There are over 200 stilbenes and stilbene glycones reported in higher plants. The most important stilbene is resveratrol, which has been extensively studied in recet years due to its antitumor potential [7,21].

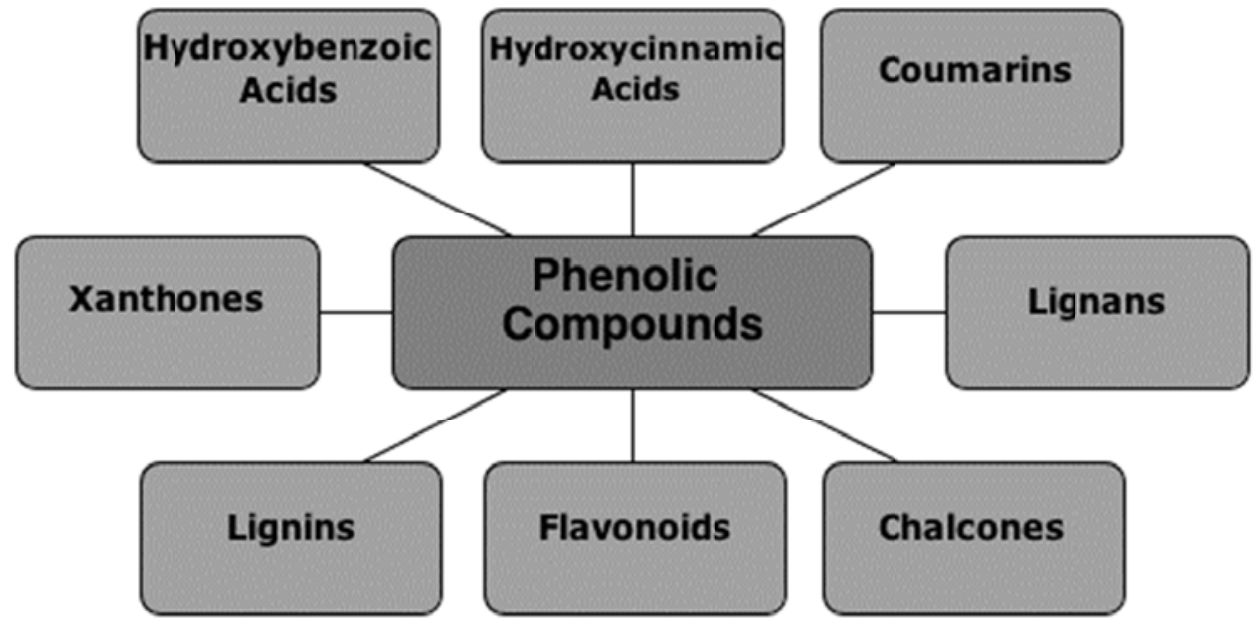

Fig. (1). Molecular groups of the phenolic compounds family. 
Table 1. Classification through number of carbons and basic structure of molecules within the phenolic compounds family.

\begin{tabular}{|c|c|c|c|}
\hline Number of Carbons & Classification & Example & Basic Structure \\
\hline 7 & Hydroxybenzoic acids & Gallic acid & \\
\hline 9 & Hydroxycinnamic acids & $p$-coumaric acid & \\
\hline 9 & Coumarins & Esculetin & \\
\hline 13 & Xanthones & Mangiferin & \\
\hline 14 & Stilbenes & Resveratrol & \\
\hline 15 & Flavonoids & Naringenin & \\
\hline
\end{tabular}

\subsubsection{Lignins}

Lignin is a polymer with many branches, composed of three simple alcohols known as monolignols. There are three major groups of lignins: lignins of softwoods (gymnosperms), lignins of hardwoods (angiosperms) and lignins of grasses (non-woody or herbaceous plants). It is the third most abundant polymer in nature, topping 300 billion metric tons on Earth. In plant tissues, lignin is bonded to other polymers like cellulose and hemicellulose. Antioxidant, anti-hypertensive and anticancer properties have been described in lignins, lignin derivatives and in complexes formed with them [24-27].

\subsubsection{Lignans}

Lignans are the result of the union of two cinnamic acid residues or their biogenic relatives. They are distributed throughout the plant kingdom in many vascular plant families, being present in all their organs. These compounds are also known for their beneficial effects, namely anticancer, antioxidant, hepatoprotective and antiviral $[28,29]$.

\subsubsection{Flavonoids}

The flavonoids are the most numerous group of molecules within the phenolic compounds and are widespread through the plant kingdom. They are polyphenolic compounds that derive from chalcones and display an arrangement of three aromatic rings (A, B and $\mathrm{C}$ ) with fifteen carbons and a $\mathrm{C} 6-\mathrm{C} 3-\mathrm{C} 6$ skeleton which can have innumerous substituents. The A ring is a benzene, condensed with a six-member ring (C), which carries a phenyl benzene in position 2 (ring B) as a substituent. Ring $\mathrm{C}$ can be a heterocyclic pyran (Table 2). Flavonoids have a mixed biosynthesis, and are products of both the shikimate and acetate pathways. They accumulate mainly in the epidermis of leaves and skin of fruits, and are involved in UV protection, pigmentation, disease resistance and stimulation of nitrogen fixing. Sugars, in the form of glycosides are normally joined with flavonoids and while they increase water solubility along with hydroxyl groups, other substituents like methyl groups and isopentenyl units increase their lipophilic properties. The main subclasses of flavonoids are flavonols,
Table 2. Representation of the basic structures of the flavonoid subclass.

Table 2. Representation of the basic structures of the flavonoid subclass.

\begin{tabular}{|c|c|c|}
\hline Classification & Examples & Basic Structure \\
\hline Flavonol & $\begin{array}{l}\text { Quercetin } \\
\text { Kaempferol } \\
\text { Myricetin }\end{array}$ & \\
\hline Flavone & $\begin{array}{l}\text { Apigenin } \\
\text { Chrysin }\end{array}$ & \\
\hline Flavanol & Catechin & \\
\hline Isoflavone & Genistein & \\
\hline Flavanone & Hesperidin & \\
\hline Anthocyanin & $\begin{array}{l}\text { Pelargonidin } \\
\text { Cyanidin }\end{array}$ & \\
\hline
\end{tabular}


flavones, flavanols or flavan-3-ols, isoflavones, flavanones and anthocyanidins [7, 10, 30-32]. Table 2 represents the basic structure and some examples of all these subclasses.

\subsubsection{Flavonols}

Flavonols are considered, not without debate, the most widespread flavonoids throughout the plant kingdom, and considered, along with flavones, the major subclass of flavonoids. The most abundant compounds within the flavonols are myricetin, quercetin and kaempferol that tend to occur as $O$-glycosides. Conjugation usually occurs at the third carbon of the C-ring, although conjugations have also been found at positions $5,7,4$ ', 3 ' and 5'. It is estimated that in Western countries the daily intake of flavonols is between 20 to $50 \mathrm{mg}$, and although these compounds are found in many fruits and vegetables, considerable quantity differences may be found between the same species, due to seasonal changes, varietal and edaphoclimatic variations. The benefits of flavonols consumption are related to protection against atherosclerosis, osteoporosis, diabetes mellitus and certain cancers [7, 32, 33].

\subsubsection{Flavones}

The flavones are structurally related to flavonols and are also considered a major subclass within the flavonoids; they occur usually as 7-O-glycosides, although other substitutions can be found. These compounds derive directly from flavanones, by abstraction of two hydrogen atoms and introduction of a double bond between carbons 2 and 3. Flavones seem to have protective and communication roles in plants, protecting against UV radiation and interacting with microbes, insects and other plants. The most common compounds within the flavones are apigenin, chrysin and luteolin. The main benefits to human health from flavones are antioxidant, anticarcinogenic, antiviral, anti-inflammatory and antiatherosclerotic [7, 34]

\subsubsection{Flavanols}

The flavanols or flavan-3-ols are the most complex subclass of flavonoids; they encompass simple molecules like catechin and large polymeric proanthocyanidins. This subclass of flavonoids, unlike the others is not planar due to a saturated C3 element in the heterocyclic C-ring. In plant systems, the flavanols act against harmful intruders like microbes, insects and herbivores; they also have the ability to chelate metals and to confer resistance to high lead levels. In food, flavanols are responsible for astringency, bitterness, sourness, salivary viscosity, aroma and color formation. The average daily consumption of flavanols in the United States was $57.7 \mathrm{mg} /$ person in between 2004 and 2005. Once inside the body, these compounds have shown antioxidant, anticarcinogen, antiviral and neuroprotective effects [7, 35].

\subsubsection{Isoflavones}

The isoflavones, also known as phytoestrogen compounds due to their phytoestrogenic activity, differ from other subclasses within the flavonoids class by having the B-ring attached to the $\mathrm{C} 3$ carbon rather than the $\mathrm{C} 2$. Isoflavones are only found in leguminous plants, being soybeans the highest producer. The main representatives of the isoflavones are genistein and daidzein along with their respective acetyl, malonyl and aglycone forms. Isoflavones have been reported to have antitumor activity along with antioxidant and antiviral potential, although some data is controversial [7, 36-38].

\subsubsection{Flavanones}

The flavanones are usually considered a minor subclass within the flavonoids due to their limited occurrence, mainly in fruits and especially in citrus. They are characterized by the absence of a double bond and a chiral center in the $\mathrm{C}$ ring. Chalcones are usually incorporated into this subclass due to being similar to flavanones; the main difference is the open $\mathrm{C}$ ring in chalcones, and the possibility of conversion of flavanones into chalcones in alkaline media and vice-versa in acidic environments. Examples of flavanones are hesperidin (orange juice) and naringine (grapefruit) and due to the high levels of hesperidin in orange juice, it has a sour taste, while naringine is sweeter. Flavanones have also been reported to have anticancer properties and effective in preventing cardiovascular diseases [7, 39-41].

\subsubsection{Anthocvanidins}

Anthocyanidins, also known as condensed tannins are present throughout the plant kingdom, especially in their glycated forms; the anthocyanins are found in fruits and flowers in a higher quantity, but also in leaves, stems and roots. These molecules are responsible for conferring red, blue and purple colors in plants as well protecting them from excessive light and attracting pollinators. The most abundant anthocyanidins are pelargonidin, cyaniding, delphinidin and peonidin. Conjugation with other molecules can take place in positions 3, 5, 7, 3' and 5', creating bigger molecules. In terms of human health, anthocyanins have been reported to have anti-inflammatory potential, DNA protection and regulator of immune responses [7, 42-45].

\section{CANCER MECHANISMS}

Cancer may have various endogenous causes (e.g. inherited mutations, hormones, and immune conditions) which are inevitable, but also exogenous ones, like tobacco consumption, diet related, radiation, and infectious organisms. The close link between cancer and oxidative stress, arising from various sources, gives way to some debate within the scientific community due to the role of prooxidants. While some scientists point them as potentially carcinogenic, others disagree and appoint out their benneficial mitigating effect on certain types of cancer [46]. Despite this controversy, prooxidants are known to be involved in carcinogenesis. According to Anand et al. [47], whom reviewed the literature and stated that "cancer is a preventable disease that requires major lifestyle changes", only 5 to $10 \%$ of cancers were caused by genetic defects and the remaining 90 to $95 \%$ were due to environment and lifestyle. This could be a promising premise, but, attending to the current number of smokers worldwide, the nutritional imbalanced diets of developed and developing countries and the wrong behaviors regarding Sun exposure, the cases of cancer are estimated to grow. In fact, considering that by 2050, 27 million new cancer cases and 17.5 million deaths are estimated to occur [48] it is imperative to understand cancer mechanisms in order to intervene with the right methodologies.

Meng et al. [49] reviewed the major theories that lead to cancer, available since the beginning of the century, and divided them into 8 categories:

- Cancer caused by viruses

- Chromosomal abnormalities

- Somatic mutations

- Accumulated multiple mutations

- Immunological surveillances

- Nonhealing wounds

- Nonmutagenic mechanisms

- Tissue organization field theories

Regarding cancer caused by viruses, when Francis Peyton Rous claimed in 1911 that cancer could be induced by a virus, the scientific community discredited his work, and only 50 years later was hiswork recognized with a Nobel Prize of Physiology or Medicine. Today, it is widely known that viruses like Epstein-Barr, Hepatitis B, Human T-cell lymphototropic type 1, Papillomavirus, Hepatitis C, Kaposi's sarcoma-associated herpesvirus and Merkel cell polyomavirus can induce carcinogenesis. Although some oncogenic viruses are common among humans, not all infections lead to cancer. The biggest setback in this field is the multitude of 
mechanisms used by each virus to induce cancer, but the scientific community is also using them to counter-attack [50-52].

In terms of chromosomal abnormalities, many tumors have the same genesis, either by nonrandom deletion or aberration of specific parts of chromosomes. In 2000 more than 600 recurrent balanced chromosome rearrangements had been identified [53, 54].

It is known that changes in the immune system, hormonal status, gene expression, and signaling between tissues have a key role in terms of probability and timing of cancer progression, but somatic mutation is the only process that determines progression of tissues at all ages, explaining the variation in age of cancer incidence. The somatic mutation theory premises are: 1) cancer is derived from a single somatic cell that has accumulated multiple DNA mutations; 2) the default state of cell proliferation in metazoa is quiescence; 3 ) cancer is a disease in cell proliferation caused by mutations in genes that control proliferation and the cell cycle. The sporadic cancers that derive from somatic mutation represent $95 \%$ of all cancers, and are some of the most researched throughout the world. It is now generally accepted that most tumors don't perpetuate themselves with only one mutation; many mutated chromosomes have been found in tumors and the rate and complexity of the mutations dictate the speed and danger of each type of cancer [55-57].

Immunological surveillance was first hypothesized by Burnet and Thomas [58, 59], back in 1959, postulating that the immune system can recognize and destroy nascent transformed cells. After being abandoned, this theory regained prominence in 1990, when the usage of animal models confirmed a cancer immunoediting mechanism. There are three essential phases: 1) elimination; 2) equilibrium and 3) escape. Initially, nascent transformed cells are eliminated by immune effector cells as part of an innate response. In the equilibrium stage, the elimination of the transformed cells sculpts the immune system inducing tumor variants decreasing immunogenicity and becoming resistant to effector cells. Finally in the escape phase, tumor-derived factors induce several escapes from immune attack, therefore promoting the tumor growth [60, $61]$.

The theory that cancer could be related with wound healing started with Alexander Haddow and, short after, Harold Dvorak, whom described cancer as a nonhealing wound. Today, it is known that wound healing shares common features with tumor genesis; in fact, both tissue regeneration and tumorigenesis involve cell proliferation, survival and migration, which are controlled by growth factors and cytokines as well as inflammatory and angiogenic signals. Understanding the similarities between wounds and the development of cancer as well as the wrong healing patters may help understand the uncontrolled growth of tumors [62-64].

The nonmutagenic mechanisms of carcinogenesis are based on the fact that the development of a tumor might not be due to mutations or aberrations in the DNA, but to mitogens and cytotoxic carcinogens. Regarding mitogens, these can cause increased cell replication without displaying any cytotoxicity by interacting directly with cell receptors. A result of this uncontrolled replication is pleiotropic responses like enzyme induction, cytomegaly and peroxisome proliferation. On the other hand, cytotoxic carcinogens induce histopathological lesions, necrosis and the release of specific enzymes into the serum. Cell proliferation resulting of cytotoxic compounds replaces the cells that are damaged after this aggression, and may stimulate growth of spontaneously occurring preneoplastic cells. This increased cell division may also induce genetic damage by increasing the number of genetic errors due to rapid cell division and reduced time for accurate DNA repair [65, 66].

Finally, the organization field theory is based on the hypothesis that carcinogenesis is a problem of tissue organization and that proliferation is the default state of all cells. The underlying mechanism of this theory states that carcinogens disrupt the normal interactions between cells in the stroma and parenchyma of a given organ. This disruption would reduce the cell's understanding of its positional and historical background. The alteration of the stromaepithelium would result in a hyperplastic state. The last step in this hypothesis would be the modification of the tissue pattern that could result in dyplasia or even in metaplasia $[67,68]$.

All cancer theories have limitations and fail to explain thoroughly certain types of cancer as well as the underlying mechanisms behind them. While some research groups look deeper into the genesis of a tumor, others venture into how natural or synthetic compounds can destroy the tumor.

\section{FIGHTING CANCER WITH PHENOLIC COMPOUNDS}

In 2003, when the complete human genome was sequenced, many scientists throughout the world considered it a landmark for the future treatment of genetic and non-genetic diseases [69]. Although many advances have been made, natural compounds did not lose their influence, in fact, between 1981 and 2006, 47.1\% of the 155 clinically approved anti-cancer drugs, were unmodified natural products or their semi-synthetic derivatives or even synthesized molecules based on natural models.

Some of the biggest contributions in terms of pure molecules come from the secondary metabolites of plants, namely polyphenols, and have had important roles both "in vitro" and "in vivo":

\subsection{Hydroxybenzoic Acids}

The most studied compounds in this group are gallic, ellagic and ferulic acids (Table 3). In terms of "in vitro" chemotherapeutic assays, in 2007, Madlener et al. [70] used gallic acid in leukemic cell lines and reported an inhibition of ribonucleotide reductase (enzyme that catalyzes the formation of deoxyribonucleotides from ribonucleotides) activity in tumor cells, resulting in a halt to tumor growth. Early and late apoptosis was dependent on the concentration of gallic acid. In another study regarding leukemia, gallic acid induced apoptosis by inhibiting BCR/ABL kinase (an oncogene), NF-kB (protein complex that is responsible for DNA transcription) and COX-2 (enzyme involved in cancer expression by promoting cell division and inhibiting apoptosis) [71]. This acid also proved to be effective against glioma cell lines in a dose dependent manner. Moreover it had a selective cytotoxicity to the glioma cells when compared to sane brain cells and decreased cell viability, proliferation and reduced angiogenesis [72]. Gallic acid also had remarkable effects on lung cancer cell lines by inducing apoptosis and activating caspases (apoptotic enzymes). In murine models, gallic acid seemed to reduce the rate of tumor gowth [73]. Regarding ellagic acid, a study carried out in 2011, used this compound against murine colon cancer and reported some interesting results; the mice were inoculated with 1,2-dimethyl hydrazine (carcinogenic inducing compound) for 15 weeks and then treated with ellagic acid for the following 15 . This hydroxybenzoic acid prevented the activation of PI3K/Akt pathway (associated with colon carcinogenesis) which down regulated $\mathrm{Bcl}-2$ proteins (apoptosis regulator proteins), increased Bax levels (pro-apoptotic protein) and activated caspase-3. Finally, this cascade of events resulted in elevation of cytochrome $\mathrm{c}$ and consequent apoptosis of the cancer cells [74]. Ellagic acid also seems to be promising for local chemotherapy. Kim et al. [75] used a chitosan/ellagic acid composite implanted subcutaneously in rats with glioma and reported angiogenesis suppressing capabilities as well as apoptosis in an ellagic acid concentration-dependent manner.

Ferulic acid seems to have some type of chemopreventive effect when administered orally, both in skin and mammary murine cancers by preventing the formation of these tumors. Although the mechanisms of this effect are not fully understood, the results are promising $[76,77]$. 
Table 3. Hydroxybenzoic acids and related compounds with reported antitumor activity.

\begin{tabular}{|c|c|c|c|c|}
\hline Compound & Type of Tumor & Type of Assay & Result Summary & Reference \\
\hline \multirow{3}{*}{ Gallic acid } & Leukemia & In vitro human cell lines & $\begin{array}{l}\text { Ribonucleotide reductase inhibition } \\
\text { Apoptosis }\end{array}$ & {$[70]$} \\
\hline & Glioma & In vitro human In vitro murine cell lines & Cell viability, proliferation and angiogenesis decrease & {$[72]$} \\
\hline & Lung carcinoma & $\begin{array}{l}\text { In vitro human cell lines } \\
\text { In vivo murine models }\end{array}$ & $\begin{array}{l}\text { Apoptosis and DNA damage } \\
\text { Activation of caspases } \\
\text { Tumor inhibition in vivo }\end{array}$ & {$[73]$} \\
\hline \multirow[t]{2}{*}{ Ellagic acid } & Colon carcinoma & In vivo murine models & $\begin{array}{l}\text { Prevention of P13k/Akt activation } \\
\text { Bax expression and caspases- } 3 \text { activation leading to } \\
\text { apoptosis }\end{array}$ & {$[74]$} \\
\hline & Glioma & In vivo murine models & $\begin{array}{l}\text { Angiogenesis suppressing } \\
\text { Apoptosis }\end{array}$ & {$[75]$} \\
\hline \multirow{2}{*}{ Ferulic acid } & Skin carcinoma & In vivo murine models & Prevention of tumor formation & {$[76]$} \\
\hline & Mammary carcinoma & In vivo murine models & Prevention of tumor formation & {$[77]$} \\
\hline $\begin{array}{l}\text { Cuphiin D1 } \\
\text { (tannin) }\end{array}$ & $\begin{array}{l}\text { Leukemia } \\
\text { Epidermoid carcinoma } \\
\text { Hepatocellular carcinoma } \\
\text { Prostate carcinoma Cervical } \\
\text { carcinoma Murine sarcoma-180 }\end{array}$ & $\begin{array}{l}\text { In vitro human cell lines } \\
\text { In vitro murine cell lines }\end{array}$ & $\begin{array}{l}\text { Apoptotic properties } \\
\text { Tumor inhibition }\end{array}$ & $\begin{array}{l}{[80]} \\
{[78]}\end{array}$ \\
\hline $\begin{array}{l}\text { Oenothein B } \\
\text { (tannin) }\end{array}$ & $\begin{array}{l}\text { Mammary carcinoma } \\
\text { Fibrosarcoma } \\
\text { Leukemia } \\
\text { Epidermoid carcinoma } \\
\text { Hepatocellular carcinoma } \\
\text { Prostate carcinoma Cervical } \\
\text { carcinoma Murine sarcoma-180 }\end{array}$ & $\begin{array}{l}\text { In vivo } \\
\text { murine models } \\
\text { In vitro human cell lines } \\
\text { In vitro murine cell lines }\end{array}$ & $\begin{array}{l}\text { Macrophages activation } \\
\text { Tumor inhibition }\end{array}$ & $\begin{array}{l}{[79]} \\
{[78]}\end{array}$ \\
\hline Cuphiin D2 & $\begin{array}{l}\text { Mammary carcinoma } \\
\text { Fibrosarcoma } \\
\text { Leukemia } \\
\text { Epidermoid carcinoma } \\
\text { Hepatocellular carcinoma } \\
\text { Prostate carcinoma Cervical } \\
\text { carcinoma Murine sarcoma-180 }\end{array}$ & $\begin{array}{l}\text { In vivo } \\
\text { murine models } \\
\text { In vitro human cell lines } \\
\text { In vitro murine cell lines }\end{array}$ & $\begin{array}{l}\text { Macrophages activation } \\
\text { Tumor inhibition }\end{array}$ & {$[78]$} \\
\hline Woodfordin C & $\begin{array}{l}\text { Mammary carcinoma } \\
\text { Fibrosarcoma } \\
\text { Leukemia } \\
\text { Epidermoid carcinoma } \\
\text { Hepatocellular carcinoma } \\
\text { Prostate carcinoma Cervical } \\
\text { carcinoma Murine sarcoma-180 }\end{array}$ & $\begin{array}{l}\text { In vivo } \\
\text { murine models } \\
\text { In vitro human cell lines } \\
\text { In vitro murine cell lines }\end{array}$ & $\begin{array}{l}\text { Macrophages activation } \\
\text { Tumor inhibition }\end{array}$ & {$[78]$} \\
\hline
\end{tabular}

Tannins, a sub-class of hydroxybenzoic acids also manifest some antitumoral activity. Cuphiin D1, an hydrolysable tannin proved to have some apoptotic properties against leukemia cell lines [78], another tannin, oenothein $\mathrm{B}$, proved to be effective against mammary carcinoma and fibrosarcoma in murine models by activating macrophages [79]. Wang et al. [80] carried out a study with four tannis extracted from Cuphea hyssopifolia. They tested cuphiin D1, cuphiin D2, oenothein B and woodfordin C against human oral epidermoid carcinoma, human promyelocytic leukemia, human hepatocellular carcinoma, human prostate carcinoma, human cervical carcinoma and mouse sarcoma cell lines. Surprisingly, all the tested tannins inhibited the growth of the tumors and revealed lower cytotoxicity than Adriamycin (a commercially available antibiotic used in certain types of cancer) in a normal cell line. Moreover, these tannins also inhibited the viability of sarcoma tumor cell lines as well as in vivo mice models.

\subsection{Hydroxycinnamic Acids}

One of the most important compounds within the hydroxycinammic acids is caffeic acid which displays some anticancer activities (Table 4). Chen et al. [81] used its derivative, caffeic acid phenethyl ester (CAPE) in human leukemic cell lines and reported an arrest on the tumor growth. At the time, the authors didn't understand the mechanisms leading to the activity. Two decades afterwards, Kuo et al. [82] used the same caffeic acid derivative on human glioma cell lines, and described an inhibition of growth of the cells by decreasing the hyperphosphorylation of the protein retinoblastoma, that when in this state is incapable of suppressing tumors. Furthermore, they found that CAPE upregulates cyclin dependent kinase inhibitors p16, p21 and p27. After this preliminary assay, murine xenografts were attempted and proved that CAPE decreased the size of tumors in a dose dependent manner by reducing the number of mitotic cells and proliferating cell nuclear antigen positive cells. Other authors have also proved the excellent results of CAPE against glioma cell lines, by inactivating DNA and arresting the cell cycle of the tumor cells [83, 84]. Cinnamic acid also displays an antitumor activity, namely against colon adenocarcinoma by antiproliferative methods like enzyme induction and modulation of the cAMP signaling pathway [85]. Cinnamic acid derivatives, drupanin and baccharin, inhibits the growth of HeLa-60 cell lines by inducing apoptosis [86]. Panobinostat, is an anticancer drug that derives from the hydroxycinnamic acid group and acts by inhibiting histone deacetylase, which intervenes in carcinogenic pathways [87, 88]. Despite already being commercialized, hepatic clinical studies are still being carried out to access its efficacy [89]. 


\subsection{Coumarins}

Coumarins represent a group of compounds that have been described as having antitumoral activity to a certain extent. Within this group, compounds such as coumarin, 4-hydroxycoumarin, 7hydroxycoumarin, psoralidin, warfarin, dicoumarol, daphetin and aesculetin, as well as complexes with other compounds, have been studied for anticancer properties (Table 5). In terms of in vitro studies, coumarin and its derivatives, along with 7hydroxycoumarin, had activity against human pancreatic [90] and lung [91] cancer cell lines. Jung et al. [92] synthesized 4hydroxycoumarin derivatives and tested them against various human cancer cell lines (lung, ovarian, melanoma, brain and colon), postulating that three of these derivatives had satisfactory anticancer effects against the cell lines and one of them had excellent results. Psoralidin is known to have an antitumor effect by inducing TRAIL-mediated apoptosis in cervical cancer. TRAIL is an apoptosis-inducing ligand of the TNF superfamily [93]. Daphetin seemed to exhibit anticancer results against renal carcinoma cells by activating p 38 and inhibiting $S$ phase of the cell cycle, but did not promote apoptosis [94]. Dicoumarol, another compound from the coumarin family doesn't seem to inhibit cancer cell lines, but in turn enhances the activity of anticancer drugs like cisplatin [95] and doxorubicin [96]. Aesculetin has also demonstrated apoptotic activity against cervical cancer cell lines [97]. Complexes between coumarins and other molecules are also prone to inhibit cancer cell lines in vitro. Thati et al. [98], demonstrated that a complex between copper-coumarin-dioxyacetic acetate-phenathroline ([Cu(cdoa)(phen)2]) against kidney adenocarcinoma and hepatocellular carcinoma displayed satisfactory antiproliferative effect, especially for the liver cancer cell lines. Not many in vivo studies have been reported regarding coumarins, although the in vitro studies have opened the opportunity for this. Lake [99] reviewed coumarin metabolism, toxicity and carcinogenicity in rodents and humans and postulated that although this compound could induce cancer in rodents it was safe to be consumed by humans due to an excretion metabolic pathway present in humans that is a minor one in rodents, generating toxicity to them. Moreover, he reviewed the anticancer in vivo studies and reported that coumarin inhibited forestomach and mammary cancer in mice as well as spontaneous tumors in transgenic mice. Finally, he also reviewed the clinical trials that this compound was involved in, and concluded that the side effects were mild and hepatotoxicity was reverted after the treatment with coumarin was terminated. Marshall et al. [100], reported that coumarin had a stationary effect in 12 of 45 patients with metastic renal cell carcinoma, while Nolte et al. [101] reported that the combined treatment of coumarin and cimetidine (histamine $\mathrm{H}_{2}$ receptor antagonist) had no effect on 17 patients with advanced malignant melanoma. Recently, a study published on clinicaltrials.gov reported that the combined treatment of the coumarin warfarin with vatalanib, could help patients with advanced solid tumors. While the kinase inhibitor vatalanib stopped

Table 4. Hydroxycinnamic acids and related compounds with reported antitumor activity.

\begin{tabular}{|l|l|l|l|}
\hline Compound & Type of Tumor & Type of Assay & Result Summary \\
\hline \hline \multirow{3}{*}{$\begin{array}{l}\text { Caffeic acid phenethyl } \\
\text { ester }\end{array}$} & Leukemia & In vitro human cell lines & Oncogene suppression and tumor inhibition \\
\cline { 2 - 4 } & Glioma & $\begin{array}{l}\text { In vitro murine cell lines } \\
\text { In vivo murine xenografts }\end{array}$ & $\begin{array}{l}\text { Hyperphosphorylation decrease of retinoblastoma } \\
\text { Up-regulation of kinase inhibitors p21, p27 and p16 }\end{array}$ \\
\cline { 2 - 5 } & Glioma & In vitro murine cell lines & p38 MAPK mediation of CAPE-induced p53-dependent apoptosis \\
\hline \multirow{2}{*}{ Cinnamic acid } & Glioma & $\begin{array}{l}\text { In vitro murine cell lines } \\
\text { In vivo murine xenografts }\end{array}$ & $\begin{array}{l}\text { Inhibition of motility } \\
\text { Induction of tumor suppressor RhoB } \\
\text { Metastasis inhibition }\end{array}$ \\
\cline { 2 - 4 } & Colon adenocarcinoma & In vitro human cell lines & $\begin{array}{l}\text { Enzyme induction } \\
\text { Modulation of cAMP signaling pathway }\end{array}$ \\
\hline Cinnamic acid derivatives & Cervical carcinoma & In vitro human cell lines & Apoptosis \\
\hline
\end{tabular}

Table 5. Coumarins and related compounds with reported antitumor activity.

\begin{tabular}{|c|c|c|c|c|}
\hline Compound & Type of Tumor & Type of Assay & Result Summary & Reference \\
\hline Coumarin derivatives & Pancreatic cancer & In vitro human cell lines & Cytotoxicity to cancer cells & {$[90]$} \\
\hline $\begin{array}{l}\text { Courmarin } \\
\text { 7-hydroxycoumarin }\end{array}$ & Lung carcinoma & In vitro human cell lines & $\begin{array}{l}\text { Inhibition of cell proliferation } \\
\text { Apoptosis induction }\end{array}$ & {$[91]$} \\
\hline 4-hydroxycoumarin derivatives & $\begin{array}{l}\text { Lung carcinoma Ovarian carcinoma Melanoma } \\
\text { Brain carcinoma } \\
\text { Colon carcinoma }\end{array}$ & In vitro human cell lines & Cytotoxicity to cancer cells & {$[92]$} \\
\hline Psoralidin & Cervical carcinoma & In vitro human cell lines & TRAIL mediated apoptosis & {$[93]$} \\
\hline Daphetin & Renal carcinoma & In vitro human cell lines & $\begin{array}{l}\text { Activation o p38 } \\
\text { Cell cycle arrest }\end{array}$ & {$[94]$} \\
\hline Dicoumarol & $\begin{array}{l}\text { Bladder carcinoma } \\
\text { Prostate carcinoma }\end{array}$ & In vitro human cell lines & Enhancement of anticancer drugs & $\begin{array}{l}{[95]} \\
{[96]}\end{array}$ \\
\hline Aesculetin & Cervical carcinoma & In vitro human cell lines & ROS mediated apoptosis & {$[97]$} \\
\hline $\begin{array}{l}\text { Copper-coumarin-dioxyacetic } \\
\text { acetate-phenathroline complex }\end{array}$ & $\begin{array}{l}\text { Kidney adenocarcinoma } \\
\text { Hepatocellular adenocarcinoma }\end{array}$ & In vitro human cell lines & Antiproliferative effect & {$[98]$} \\
\hline Coumarin & Renal carcinoma & Epidemiological studies & Enhancement of anticancer drug & {$[100]$} \\
\hline Warfarin & Solid tumors & Epidemiological studies & Side effect of anticancer drug reduction & {$[102]$} \\
\hline
\end{tabular}


the tumor growth by inhibiting angiogenesis, warfarin prevented the formation of blood clots [102].

\subsection{Xanthones}

Xanthones are a small group of compounds that have also proven interesting as natural anticancer molecules. The most notorious origin of xanthones is the fruit of the purpule magosteen (Garcinia mangostana), yielding a number of xanthones, especially $\alpha$-, $\beta$ - and $\gamma$-mangostin which are also the most studied compounds of this group (Table 6). These three compounds have been described as in vitro chemopreventive and chemotherapeutic agents against, colon carcinoma [103-105], leukemia [106], melanoma [107], neck carcinoma [108], glioblastoma [109] and others [110]. Ho et al. [111] investigated the in vitro activity of 6 xanthones against 14 cell lines, and postulated that garcinone $\mathrm{E}$ was the best compound among the studied by inducing apoptosis in hepatoma, gastric and lung cancer cells proving to be more potent than commercial anticancer drugs. Other xanthones have also been investigated to a lesser extent against cholangiocarcinoma. These compounds, isomorellin, isomorellinol, forbesione and gambogic acid inhibited growth of those cancer cells in a dose dependent manner, being isomorellinol the most potent compound [112]. Although this group of polyphenols seems to have promising molecules with regard to in vitro assays, virtually no record of in vivo or clinical trials is reported against cancer. This might be due to a poor understanding of the mechanism of action of xanthones, which should be investigated thoroughly [113].

\subsection{Chalcones}

Chalcones are a family of polyphenols with a wide spectrum of biological activities, namely antioxidant, antibacterial, antiinflammatory, immunosuppressive and anticancer. Phloretin, a very bioactive chalcone has been tested against human melanoma cell lines, and displayed apoptotic effect against the cancer cells [114] (Table 7). This same compound was found to potentiate the effect of paclitaxel, an anticancer commercial drug that inhibits cell mitosis [115]. Arbutin also displayed a remarkable effect against melanoma cell lines by down regulating cancer genes [116]. Szliszka et al. [117] tested 2 chalcones (chalcone and 2',6'dihydroxy4'-methoxychalcone) and 3 dihydrochalcones (2',6'-dihydroxy-4'4dimethoxydihydrochalcone, 2',6'-dihydroxy-4'-methoxydihydrochalcone, and phloretin) against human prostate cancer cells and discovered that all the compounds induced TRAIL mediated apoptosis against the cell lines. Synthetic chalcones have also been the target of many studies. Although they are synthesized in laboratorial conditions and not isolated from plants, their effect on various cell lines has also been satisfactory [118-121]. In 2011, Orlikova et al. [122] published a review regarding the chemopreventive and chemotherapeutic potential of dietary chalcones, where all the studies surrounding the effects of chalcones against cancer (in vitro and in vivo) were compiled. The authors concluded that some chalcones could intervene in a beneficial way in several steps of carcinogenesis and could be included in anticancer therapies. Moreover, the chalcones should be extensively studied in order to identify and characterize the naturally occurring ones while laboratorial synthesis to potentiate their effects should also be encouraged.

\subsection{Stilbenes}

This small group of compounds, although comprised of hundreds of compounds, one of them stands high above the others, resveratrol. This compound, mainly found in grapes has been described as a chemopreventive and chemotherapeutic agent (Table 8). The first record of its chemopreventive activity dates back to 1997 [123]. Since then, resveratrol and its analogues have undergone assays for virtually all human cancers. It has been screened in vitro against kidney and breast cancer [124], leukemia [125] and many others. In murine models, resveratrol also exhibits good anticancer effects and is also described as a sensitizer for anticancer drugs [126]. Resveratrol has taken part in various epidemiological studies, namely for gastro intestinal tumors [127], colorectal cancer [128],

Table 6. Xanthones with reported antitumor activity.

\begin{tabular}{|c|c|c|c|c|}
\hline Compound & Type of Tumor & Type of Assay & Result Summary & Reference \\
\hline $\begin{array}{l}\alpha \text {-Mangostin } \\
\beta \text {-Mangostin } \\
\gamma \text {-Mangostin }\end{array}$ & $\begin{array}{l}\text { Colon carcinoma } \\
\text { Leukemia } \\
\text { Melanoma } \\
\text { Neck carcinoma } \\
\text { Glioblastoma }\end{array}$ & In vitro human cell lines & $\begin{array}{l}\text { Apoptosis } \\
\text { Cell cycle arrest }\end{array}$ & $\begin{array}{l}{[103]} \\
{[104]} \\
{[105]} \\
{[106]} \\
{[107]} \\
{[108]} \\
{[109]}\end{array}$ \\
\hline Garcinone E & $\begin{array}{l}\text { Hepatocellular carcinoma } \\
\text { Lung carcinoma } \\
\text { Gastric carcinoma }\end{array}$ & In vitro human cell lines & $\begin{array}{l}\text { Apoptosis } \\
\text { Cell cycle arrest }\end{array}$ & [111] \\
\hline $\begin{array}{l}\text { Isomorellin } \\
\text { Isomorellinol } \\
\text { Forbesione } \\
\text { Gambogic acid }\end{array}$ & Cholangiocarcinoma & In vitro human cell lines & $\begin{array}{l}\text { Apoptosis } \\
\text { Cell cycle arrest }\end{array}$ & [112] \\
\hline
\end{tabular}

Table 7. Chalcones with reported antitumor activity.

\begin{tabular}{|c|c|c|c|c|}
\hline Compound & Type of Tumor & Type of Assay & Result Summary & Reference \\
\hline \multirow{2}{*}{ Phloretin } & Melanoma & In vitro human cell lines & Apoptosis & [114] \\
\hline & Hepatoma & In vitro human cell lines & Enhancement of anticancer drug & [115] \\
\hline Arbutin & Melanoma & In vitro human cell lines & Down regulation of cancer genes & {$[116]$} \\
\hline $\begin{array}{l}\text { Chalcone } \\
\text { 2',6'dihydroxy-4'-methoxychalcone } \\
\text { 2',6'-dihydroxy-4'4-dimethoxydihydrochalcone 2',6'- } \\
\text { dihydroxy-4'-methoxydihydrochalcone Phloretin }\end{array}$ & Prostate carcinoma & In vitro human cell lines & TRAIL mediated apoptosis & {$[117]$} \\
\hline
\end{tabular}


Table 8. Stilbenes with reported antitumor activity.

\begin{tabular}{|c|c|c|c|c|}
\hline Compound & Type of Tumor & Type of Assay & Result Summary & Reference \\
\hline \multirow[t]{2}{*}{ Resveratrol } & $\begin{array}{l}\text { Leukemia } \\
\text { Mammary carcinoma } \\
\text { Skin carcinoma }\end{array}$ & $\begin{array}{l}\text { In vitro human cell lines } \\
\text { In vivo murine xenografts }\end{array}$ & $\begin{array}{l}\text { Cell differentiation induction } \\
\text { Inhibition of preneoplastic lesions } \\
\text { Tumorigenesis inhibition }\end{array}$ & {$[123]$} \\
\hline & $\begin{array}{l}\text { Breast carcinoma } \\
\text { Kidney carcinoma }\end{array}$ & $\begin{array}{l}\text { In vitro human cell lines } \\
\text { In vivo murine xenografts }\end{array}$ & Promotion of Argonaute 2 expression & {$[124]$} \\
\hline \multirow{5}{*}{ Resveratrol } & Leukemia & In vitro human cell lines & $\begin{array}{l}\text { Apoptosis } \\
\text { Cell cycle arrest }\end{array}$ & {$[125]$} \\
\hline & $\begin{array}{l}\text { Neuroblastoma } \\
\text { Glioma } \\
\text { Pancreatic carcinoma } \\
\text { Breast carcinoma } \\
\text { Prostate carcinoma } \\
\text { Leukemia } \\
\text { Renal carcinoma }\end{array}$ & In vitro human cell lines & Sensitizer of anticancer drugs & {$[126]$} \\
\hline & Gastrointestinal carcinomas & Epidemiological studies & Ongoing & {$[127]$} \\
\hline & Colorectal carcinoma & Epidemiological studies & Undisclosed results & {$[128]$} \\
\hline & Healthy individuals & Epidemiological studies & $\begin{array}{l}\text { Lower doses of resveratrol }(1.0,2.5 \text { and } 5.0 \mathrm{~g}) \\
\text { are detectable in human plasma }\end{array}$ & {$[129]$} \\
\hline $\begin{array}{l}\text { Sophrastilbene } \\
\alpha \text {-viniferin } \\
\varepsilon \text {-viniferin } \\
\text { Rhaponticin }\end{array}$ & $\begin{array}{l}\text { Squamous cell carcinoma } \\
\text { Submandibular glad carcinoma } \\
\text { Leukemia }\end{array}$ & In vitro human cell lines & $\begin{array}{l}\text { Toxicity against cancer cells } \\
\text { Activation of caspases }\end{array}$ & {$[135]$} \\
\hline $\begin{array}{l}\text { 3,4,5-trimethoxy- } 4 \mathrm{~V} \text {-bromo- } \\
\text { cis-stilbene }\end{array}$ & Lung carcinoma & In vitro human cell lines & $\begin{array}{l}\text { DNA fragmentation } \\
\text { Apoptosis }\end{array}$ & {$[136]$} \\
\hline $\begin{array}{l}\text { 3,5-dihydroxy-4'-acetoxy- } \\
\text { trans-stilbene }\end{array}$ & $\begin{array}{l}\text { Prostate carcinoma } \\
\text { Melanoma }\end{array}$ & $\begin{array}{l}\text { In vitro human cell lines } \\
\text { In vivo murine xenografts }\end{array}$ & Limited potential in vivo & {$[137]$} \\
\hline
\end{tabular}

as a preventive measure against cancer [129]. Due to the multitude of results of the various types of assays, resveratrol has been a target of many anticancer reviews [130-132]. Pterostilbene and piceatannol, which belong to the stilbene group, have also been described as chemopreventive and chemotherapeutic agents both in vitro and in vivo $[133,134]$. Other stilbenes have also been investigated less extensively, but have also shown some type of anticancer effects, such as the compounds like sophrastilbene, $\alpha$ viniferin, $\varepsilon$-viniferin, rhaponticin [135], 3,4,5-trimethoxy-4'bromocis-stilbene [136] and 3,5-dihydroxy-4'-acetoxy-trans-stilbene [137], although very limited feedback was reported in murine xenografts.

\subsection{Lignins}

Lignins are possibly the least studied polyphenols group in terms of chemoprotective and chemotherapeutic potential. To the authors knowledge only one study was conducted to investigate the chemopreventive effect of Kraft lignins (Table 9). In that study, lignins resulting from chemical treatment of wood and paper were tested for adsorption to $\mathrm{N}$-nitrosamines in healthy human and murine cell lines in order to prevent tumorigenesis arising from nitrosamines. Košiková et al. [138] reported that the good binding of the lignins revealed protective effects of the cell's DNA.

\subsection{Lignans}

Mammalian lignans are the result of metabolisation of dietary lignans and both display beneficial effects on human health. Mammalian lignans were discovered in human urine around 1980, and by 1998, various experiments had been conducted using lignans as beneficial compounds. Among these investigations, the role of two dietary lignans (secoisolariciresinol and matairesinol) had been tested both in vitro and in vivo against breast, colon and skin cancer, and while the in vitro assays showed good inhibition concentrations, the in vivo results were, at the time, still scanty [139] (Table 9). Since then, other dietary lignans have been studied for their chemopreventive and chemotherapeutic effects Syringaresinol has been tested in vitro against leukemia and displayed cell cycle arrest at G1 phase mediated by cyclindependent kinases, followed by apoptosis demonstrated by morphological changes in a dose and time dependent manner, making this polyphenol a good candidate as a chemotherapeutic agent [140]. Another lignan, hydroxymatairesinol, has been tested in murine models with induced prostate cancer. The mice fed with hydoxymatairesinol displayed smaller tumors as well as a halt in tumor growth and in some cases regression [141]. One of the most studied lignans is podophyllotoxin for its beneficial effect against cancer. It is used as a starting compound to synthetize two commercial anticancer drugs, etoposide and teniposide [142]. The in vivo application of this polyphenol has resulted in tumor regression in murine models, although tumor regrowth would take place after treatment. Other limitations such as poor solubility in water and tumor resistance have inspired clinicians and scientists to develop water soluble compounds to overcome its solubility [143], and to join podophyllotoxin with other molecules like fatty acids to overcome tumor resistance and improve pharmacological efficacy [144]. In terms of epidemiological studies, podophyllotoxin is used in anticancer preparations along with other chemicals [145-148]. Landete [149] reviewed the lignans, from their sources, dietary intake, metabolism, metabolization to mammalian lignans, health implications and future prospects. The author covered the effects on colon, breast, prostate and intestinal cancer, which seem to be the most effective targets of this polyphenol. In terms of future perspectives, the author advised investigation to uncover the mechanisms of action at a molecular level as well as a closer look into nutrigenomics and nutrigenetics.

\subsection{Flavonoids}

\subsubsection{Flavonols}

The most active flavonols against cancer are quercetin and kaempferol (Table 10). They have been extensively studied against 
Table 9. Lignins and lignans with reported antitumor activity.

\begin{tabular}{|l|l|l|l|}
\hline Compound & Type of Tumor & Type of Assay & Result Summary \\
\hline \hline Kraft lignins & $\begin{array}{l}\text { Sane human skin cells } \\
\text { Quasidiploid hamster cells }\end{array}$ & $\begin{array}{l}\text { In vitro human cell lines } \\
\text { In vitro murine cell lines }\end{array}$ & $\begin{array}{l}\text { Adsorption to nitrosamines } \\
\text { DNA protective effect }\end{array}$ \\
\hline $\begin{array}{l}\text { (-)Syringaresinol } \\
\text { 7-Hydroxymatairesinol }\end{array}$ & Leukemia & In vitro human cell lines & $\begin{array}{l}\text { Cell cycle arrest } \\
\text { Apoptosis }\end{array}$ \\
\hline $\begin{array}{l}\text { Podophyllotoxin and polyethylene } \\
\text { glycol }\end{array}$ & $\begin{array}{l}\text { Leukemia } \\
\text { Lung carcinoma }\end{array}$ & In vivo murine models & $\begin{array}{l}\text { Cell proliferation reduction } \\
\text { Tumor reduction }\end{array}$ \\
\hline $\begin{array}{l}\text { Podophyllotoxin and fatty acids } \\
\text { analogs }\end{array}$ & $\begin{array}{l}\text { Solid tumors } \\
\text { Leukemia }\end{array}$ & $\begin{array}{l}\text { In vitro human cell lines } \\
\text { In vivo murine models }\end{array}$ & $\begin{array}{l}\text { Better tumor inhibition compared to } \\
\text { podophyllotoxin alone }\end{array}$ \\
\hline
\end{tabular}

Table 10. Flavonols with reported antitumor activity.

\begin{tabular}{|c|c|c|c|c|}
\hline Compound & Type of Tumor & Type of Assay & Result Summary & Reference \\
\hline \multirow{4}{*}{ Quercetin } & $\begin{array}{l}\text { Leukemia } \\
\text { Raji Burkitt lymphoma }\end{array}$ & In vitro human cell lines & $\begin{array}{l}\text { Morphological changes Condensation of nuclear chromatin } \\
\text { Nuclear fragmentation } \\
\text { Apoptosis }\end{array}$ & {$[150]$} \\
\hline & $\begin{array}{l}\text { Gastric adenocarcinoma } \\
\text { Hepatocellular carcinoma } \\
\text { Lung adenocarcinoma }\end{array}$ & In vitro human cell lines & $\begin{array}{l}\text { Inhibition of tyrosine kinase and of important steps of } \\
\text { angiogenesis like proliferation, migration, and tube formation } \\
\text { of human microvascular dermal endothelial cells in human }\end{array}$ & {$[151]$} \\
\hline & Various cancers & Epidemiological studies & Decrease in $\alpha$-fetoprotein & {$[157]$} \\
\hline & Prostate cancer & In vitro human cell lines & Inhibition of oncogenes and genes controlling the cell cycle & {$[152]$} \\
\hline $\begin{array}{l}\text { Quercetin and quercetin-5',8- } \\
\text { disulfonate }\end{array}$ & $\begin{array}{l}\text { Colon cancer } \\
\text { Breast cancer }\end{array}$ & In vitro human cell lines & Cell cycle arrest & {$[153]$} \\
\hline $\begin{array}{l}\text { QC12 (3'-(N- } \\
\text { carboxymethyl)carbamoyl-3- } \\
\text { 4'-5-7-tetrahydroxyflavone) }\end{array}$ & Various cancers & Epidemiological studies & Quercetin bioavailability between 20 and $25 \%$ in plasma & {$[158]$} \\
\hline Quercetin copper(II) complex & Lung adenocarcinoma & In vitro human cell lines & $\begin{array}{l}\text { Cytotoxic for the cancer cell lines } \\
\text { DNA binding } \\
\text { Apoptosis and growth inhibition }\end{array}$ & {$[155]$} \\
\hline $\begin{array}{l}\text { Quercetin in polyethylene } \\
\text { glycol } 4000 \text { lipossomes }\end{array}$ & $\begin{array}{l}\text { Lewis lung cancer } \\
\text { Colon adenocarcinoma Hepatoma }\end{array}$ & In vivo murine models & $\begin{array}{l}\text { Apoptosis } \\
\text { Growth inhibition }\end{array}$ & {$[156]$} \\
\hline \multirow[b]{2}{*}{ Kaempferol } & Hepatocarcinoma & In vitro human cell lines & Cell viability reduction & {$[159]$} \\
\hline & Pancreatic carcinoma & In vitro human cell lines & $\begin{array}{l}\text { Growth enzymes inhibition } \\
\text { Apoptosis }\end{array}$ & {$[160]$} \\
\hline Kaempferol+TRAIL & $\begin{array}{l}\text { Colon cancer } \\
\text { Prostate cancer }\end{array}$ & In vitro human cell lines & Caspase dependent apoptosis & {$[161]$} \\
\hline Kaempferol & Osteosarcoma & $\begin{array}{l}\text { In vitro human cell lines } \\
\text { In vivo murine models }\end{array}$ & $\begin{array}{l}\text { Cell viability reduction } \\
\mathrm{Ca}^{2+} \text { increase } \\
\text { Alteration of protein expression } \\
\text { Apoptosis }\end{array}$ & {$[162]$} \\
\hline
\end{tabular}

various murine and human cell lines with remarkable effects. Back in 1994, quercetin proved to be effective against chronic myeloid leukemia, Molt-4 acute lymphocytic leukemia, Raji Burkitt lymphoma in terms of morphological changes, condensation of nuclear chromatin, nuclear fragmentation and induced apoptosis in a time and concentration dependent manner [150]. Since then, quercetin has been investigated in various human cell lines. Tan et al. [151] reported an inhibition of tyrosine kinase and of important steps in angiogenesis like proliferation, migration, and tube formation of human microvascular dermal endothelial cells in human gastric adenocarcinoma, hepatocellular carcinoma and lung adenocarcinoma. Severe and moderately aggressive human prostate cancer cell lines were also inhibited by quercetin through inhibition of specific oncogenes and genes that control the cell cycle [152]. Quercetin is known to be metabolized during the human digestion and also has a very poor solubility. These drawbacks have led research groups to attempt to derive this compound, create complexes with metals or to encapsulate it in lipossomes. Derivatives like quercetin-5',8-disulfonate, proved to have anticancer properties in colon and breast cancer cell lines, by arresting the cell cycle, surpassing quercetin itself [153]. Tan et al. $[154,155]$ have combined quercetin with both copper and zinc and reported that these complexes were cytotoxic for the cancer cell lines and by binding to the DNA induced apoptosis and growth inhibition. Finally, Yuan et al. [156] proposed encapsulation of quercetin in polyethylene glycol 4000 lipossomes to overcome its poor solubility. The methodology involved intravenous (i.v.) injecting with subsequent accumulation in the tumor cells. In vivo assays with mice suffering from Lewis lung cancer, colon adenocarcinoma and hepatoma were performed. Apoptosis and 
growth inhibition was detected for all tumors, thus eliminating a considerable drawback in the application of quercetin for cancer treatment. In terms of epidemiological studies involving quercetin, the first one was conducted in 1996, this Phase I clinical trial involved 51 patients with various terminal cancers. They were administered i.v. escalating doses of quercetin with a maximum of $1700 \mathrm{mg} / \mathrm{m}^{2}$ for three weeks. Nephrotoxicity was detected at the maximum concentration and a recommended concentration was fixed at $1400 \mathrm{mg} / \mathrm{m}^{2}$ for future type II trials. In one patient CA-125 (biomarker for ovarian cancer) was significantly reduced, and all the patients suffering from hepatocellular carcinoma revealed a reduction of $\alpha$-fetoprotein, which is usually high in these types of cancer. Although this was an interesting finding, no regression in the tumor was detected in radiological assays [157]. In 2001, Mulholland et al. [158], confronted with the usage of DMSO (Dimethyl sulfoxide), which is known to cause hemolysis, to overcome the staggering low solubility of quercetin in water, synthesized a quercetin derivative, QC12 (3'-(N-carboxymethyl) carbamoyl-3-4'-5-7-tetrahydroxyflavone). The authors administered $400 \mathrm{mg}$ of this compound to six terminal state cancer patients through either oral or i.v.. At this concentration, the authors found no evidence of toxicity towards the patients and, although i.v. administered QC12 had a bioavailability $20 \sim 25 \%$ of quercetin, the orally administered one was not found in the plasma. They postulated that other derivatives should be researched in order to potentiate bioavailability of quercetin.

Kaempferol has also been studied for potential anticancer properties. In terms of human cell lines, kaempferol proved to be effective against hepatocarcinoma. This type of tumor is known to create hypoxia to surrounding cells, therefore promoting its own growth and making it resistant to chemotherapy. Kaempferol proved to reduce tumor cell viability even under hypoxic conditions [159]. In two types of human pancreatic cell lines, kaempferol proved to be better than 5-FU (fluorouracil, an anticancer drug) by inhibiting growth enzymes and promoting apoptosis in a concentration dependent manner [160]. Kaempferol can also be joined with anticancer agents, like TRAIL; in a study published in 2008, Yoshida et al. [161] reported that the combined effect of these two compounds induced considerable caspase dependent apoptosis rates in colon and prostate cancer cell lines, whilst the individual compounds were very poor in apoptosis induction. As a control assay they tested kaempferol+TRAIL in normal peripheral blood mononuclear cells with low toxicity to these sane cells. Human osteosarcoma cell lines have also been inhibited by kaempferol, namely by loss of cell viability, increase in cytoplasmic $\mathrm{Ca}^{2+}$, alteration of certain protein expression and apoptosis. In vivo studies have also been trialed and a reduction in osteosarcoma tumor growth was detected [162].

\subsubsection{Flavones}

The major representative molecule within the flavones is chrysin. It has demonstrated good results in various types of cancers (Table 11). It induced caspase 3 mediated apoptosis and enhanced Akt phosphorylation by inhibiting Pi3k (enzyme responsible for cell growth) in human leukemic cell lines [163]. Like kaempferol, chrysin can also be joined with TRAIL to enhance anticancer effects. In 2011, Li et al. [164] used human nasopharyngeal carcinoma, colorectal cancer, cervix carcinoma and hepatoma cell lines to test the synergy of these compounds. Although there was no observed effect for the isolated compounds, the treatment with the mixture of both enhanced apoptosis in four cell lines. In an attempt to understand the mechanisms behind this synergy, the authors pretreated the cells with chrysin before adding TRAIL which resulted in weak results, implying that cell death was enhanced by chrysin but induced by TRAIL.

In terms of murine models, chrysin has yielded good results against diethylnitrosamine (DEN) induced heptocarcinogenesis; $250 \mathrm{mg} / \mathrm{kg}$ (body weight) of chrysin was administered to the mice and changes in enzymes and protein expression were detected, as well as a reduction in number and size of nodules formed, pointing

Table 11. Flavones with reported antitumor activity.

\begin{tabular}{|c|c|c|c|c|}
\hline Compound & Type of Tumor & Type of Assay & Result Summary & Reference \\
\hline Chrysin & Leukemia & In vitro human cell lines & Caspase 3 mediated apoptosis & {$[163]$} \\
\hline Chrysin + TRAIL & $\begin{array}{l}\text { Nasopharyngeal carcinoma } \\
\text { Colorectal cancer, Cervix } \\
\text { carcinoma Hepatoma }\end{array}$ & In vitro human cell lines & Enhancement of apoptosis & {$[164]$} \\
\hline \multirow{2}{*}{ Chrysin } & Hepatocarcinogenesis & In vivo murine models & $\begin{array}{l}\text { Changes in enzymes and protein expression Reduction } \\
\text { in number and size of nodules }\end{array}$ & {$[165]$} \\
\hline & Hepatocellular carcinoma & In vivo murine models & $\begin{array}{l}\text { Attenuated biochemical and histological changes } \\
\text { Reduction of } \alpha \text {-fetoproteins and embriogenic antigen }\end{array}$ & {$[166]$} \\
\hline Flavopiridol & 60 different cell lines & $\begin{array}{l}\text { In vitro human cell lines } \\
\text { In vitro murine cell lines } \\
\text { In vivo murine models }\end{array}$ & $\begin{array}{l}\text { Cytotoxicity against tumor cell lines } \\
\text { Tumor inhibition }\end{array}$ & {$[167]$} \\
\hline Flavone core structure & Colon adenocarcinoma & In vitro human cell lines & $\begin{array}{l}\text { Reduction of cell proliferation } \\
\text { Induction of apoptosis }\end{array}$ & {$[168]$} \\
\hline $\begin{array}{l}\text { Pectolinarin, Linariin, Isolinariin } \\
\text { A, Isolinariin B, } \\
\text { Paracetylpectolinarin, } \\
\text { Pectolinarigenin, Pectolinarigenin- } \\
\text { 7-O- } \beta \text {-Glucoside, Antirrhide and } \\
\text { Antirrhinoside }\end{array}$ & $\begin{array}{l}\text { Large lung cell carcinoma } \\
\text { Hepatocellular carcinoma } \\
\text { Renal adenocarcinoma } \\
\text { Amelanotic carcinoma } \\
\text { Colorectal adenocarcinoma }\end{array}$ & In vitro human cell lines & Reduction of cell proliferation & {$[169]$} \\
\hline Chrysing long chain derivatives & Liver carcinoma & In vitro human cell lines & Antiproliferative activity & {$[170]$} \\
\hline \multirow{2}{*}{ Flavone acetic acid } & Leukemia & In vivo murine models & Tumor supression & {$[171]$} \\
\hline & Various human carcinomas & Epidemiological studies & No reported benefitial effects & {$[174]$} \\
\hline P276-00 & Various human carcinomas & $\begin{array}{l}\text { In vitro human cell lines } \\
\text { In vivo murine models }\end{array}$ & Antiproliferative potential & {$[177]$} \\
\hline P276-00 & Breast carcinoma & Epidemiological studies & Ongoing & {$[178]$} \\
\hline
\end{tabular}


out a hepatoprotective and chemopreventive activity of this flavonol [165]. The same effect was reported in another study involving chrysin and murine models, where hepatocellular carcinoma was induced by $\mathrm{N}$-nitrosodiethylamine in mice which were then treated with chrysin, resulting in attenuated biochemical and histological changes when compared to the control group. Moreover, chrysin reduced the levels of $\alpha$-fetoproteins and embriogenic antigen (tumor markers). Finally, the most remarkable effect was a restoration of cell architecture of liver tissue, confirming a chemotherapeutic effect [166].

Flavopiridol, another effective flavonol has also been used both in vitro and in vivo against various cancers. Drees et al. [167] tested this compound in vitro against 60 different cancer cell lines. For a control assay they used sane bone marrow cell lines which only displayed sings of toxicity for concentrations above $100 \mathrm{ng} / \mathrm{ml}$. Flavopiridol displayed cytotoxicity at concentrations as low as 0.1 $\mathrm{ng} / \mathrm{ml}$, especially in prostate and melanoma xenografts. Moreover, 14 of the 23 tumor cell types were inhibited in a greater manner than the control bone marrow cells. The in vivo assays were only performed in prostate cancer, which was the most affected under in vitro assays. In this case, flavopiridol was administered in the maximum tolerated dose $(19 \mathrm{mg} / \mathrm{kg})$ to have significant activity and after the administration the tumor regrew, implying that treatment should be longer than 2 weeks.

The core structure of flavones (2-phenyl-4H-benzopyran-4one), a flavone, also indicated some antitumor activity against human colon adenocarcinoma by reducing cell proliferation and induction of apoptosis in a greater manner than campothecin (alkaloid based anticancer drug) [168].

In 2005, Tundis et al. [169] isolated all the flavones and respective derivatives from the plant Linaria reflexa, including pectolinarin, linariin, isolinariin $\mathrm{A}$, isolinariin $\mathrm{B}$, paracetylpectolinarin, pectolinarigenin, pectolinarigenin-7-O- $\beta$-glucoside, antirrhide and antirrhinoside, screening them against large lung cell carcinoma, hepatocellular carcinoma, renal adenocarcinoma, amelanotic carcinoma, colorectal adenocarcinoma and sane human fetal lung tissue as a control. All the compounds displayed interesting results against colorectal carcinoma and large lung cell carcinoma; pectolinarin was also effective against amelanotic melanoma. Pectolinarigenin and its derivatives were active against amelanotic melanoma and large lung cell carcinoma. The less sensitive cell line was renal adenocarcinoma.

In order to overcome the limitations of natural compounds in terms of bioavailability and cytotoxic effects, many research groups have started synthesizing compounds based on natural ones but removing structural limitations. Lv et al. [170] synthesized long chain derivatives of chrysin and tested them against human liver cancer. Among them, the compounds that had a higher activity were hexadecyl 2-(5-hydroxy-4-oxo-2-phenyl-4H-chromen7-yloxy)acetate and N-hexadecyl 2-(5-hydroxy-4-oxo-2-phenyl-4Hchromen-7-yloxy)acetamide displaying antiproliferative activity comparable to arlotinib (anticancer drug). Furthermore, they used docking simulations to determine the binding mode of these compounds and determined that both these compounds bonded quite well with the epidermal growth factor receptor (EGFR) postulating that they could be interesting chemotherapeutic agents.

To this date, not many flavones have been subject to epidemiological studies, except flavone acetic acid. In the mid 80's, dozens of flavones from Lyonnaise Industrielle Pharmaceutique were subjected to preliminary screening against murine leukemia. Among all the compounds tested, flavone acetic acid had the greatest activity and continued to a phase I murine study that through pharmacokinetics confirmed that a quick hydrolysis of this compound was responsible for tumor suppression. In addition, no myelosupression or major toxicity was detected. When the clinical trials escalated to human subjects, there was no antitumor activity, but this limitation was not due to poor penetration. Further studies confirmed that the mechanisms of action in murine and human species were different, leading to its poor activity in humans, and inspiring research groups to pursue the underlying mechanisms of this promising drug in the human body [171-176].

Recently, a flavone derivative has been tested against various cell lines and xenografts; this compound, P276-00 has yielded excellent results, with an antiproliferative potential of 30 -fold higher than cisplatin (a chemotherapeutic drug) and 26-fold higher tumor sensitivity. This compound has been tested against cisplatin resistant tumors of central nervous system, melanoma, prostate and renal cancers, among others. Due to the outstanding results of this molecule, in 2011, a clinical trial was started to determine the effects of P276-00 administered in escalating doses with two anticancer drugs (Gemcitabine and Carboplatin) in subjects with metastic breast cancer $[177,178]$.

\subsubsection{Flavanols}

Most of the compounds in this group derive from the catechin backbone being the most abundant compounds found in green tea. Despite the widely accepted benefits of these compounds for cancer treatment, reports of the beneficial effects of isolated compounds are not that abundant. With regard to catechin, it is known to prevent metastasis of melanoma in murine models (Table 12). This compound inhibits tumor formation and increases the life span of the animals. In vitro tests uncovered that catechin also inhibits the migration of melanoma cells across the collagen matrix of a Boyden chamber [179]. A catechin derivative, catechin hydrate, was effective in inhibiting by $50 \%$, the growth of human cervical cancer cell lines in vitro, by increasing caspase-3, -8 and -9 and by inducing apoptosis [180]. Despite the scarce studies on the isolated effects of catechin, there is a considerable amount of publications regarding conjugations of this compound with a variety of other molecules. In 2004, Farivar-Mohseni et al. [181] used the known ability of catechin to inhibit cyclooxygenase (prostanoid producing enzyme) and conjugated it with NS-398 (also a prostanoid inhibiting enzyme) and tested their synergistic capacity against various bladder and prostate cancer cell lines. For both cancer types, the synergy was evident, resulting in a reduction in cell growth and apoptosis in a more severe manner than with the isolated compounds. Catechin has also been joined with inositol hexaphosphate (a carbohydrate) against pancreatic cancer cell lines. This conjugate increased apoptosis and inhibited cell growth in a greater manner that the isolated compounds [182]. Vittorio et al. [183] used dextran, a branched glucan in conjunction with catechin against pancreatic ductal adenocarcinoma. The cancer line was killed after being exposed to this conjugate. Moreover, dextrancatechin was less toxic to normal pancreatic cells than catechin alone. Anticancer clinical trials using catechin as an anticancer or cancer preventive drug are extensive, although in some cases, there is no way of knowing if the drug is strictly composed by catechin or if derivatives like epigallocatechin, epigallocatechin-3-gallate and other are also present. A great number of these trials intend to assess the preventive effects of catechin against unspecific cancers [184], and on specific types of cancer, like cervical and esophageal $[185,186]$. Finalized studies using catechin as an experimental drug have studied bladder and prostate cancer [187-189]. An ongoing study, with a primary due date scheduled for January 2013 is studying the effect of catechin in colorectal cancer [190].

Epigallocatechin-3-gallate (EGCG) is known for being the most abundant flavanol in tea and for a wide range of health benefits. It has been tested against human eosinophilic leukemia cell lines and suppressed cell proliferation in a dose dependent manner. At a low concentration of $40 \mu \mathrm{M}$ the tumor cells underwent differentiation into mature eosinophil-like cells [191]. This compound also exhibited a considerable apoptotic effect against mouse hepatoma cell lines by cleaving procaspase- 12 and increase in phosphorylation of ElF2 $\alpha$ (subunit of ElF2 protein, responsible for an important 
Table 12. Flavanols with reported antitumor activity.

\begin{tabular}{|c|c|c|c|c|}
\hline Compound & Type of Tumor & Type of Assay & Result Summary & Reference \\
\hline Catechin & Melanoma & $\begin{array}{l}\text { In vitro human cell lines } \\
\text { In vivo murine models }\end{array}$ & Metastasis prevention & {$[179]$} \\
\hline Catechin hydrate & Cervical carcinoma & In vitro human cell lines & Inhibition of $50 \%$ of cell growth & {$[180]$} \\
\hline Catechin+NS-398 & $\begin{array}{l}\text { Bladder carcinoma } \\
\text { Prostate carcinoma }\end{array}$ & In vitro human cell lines & $\begin{array}{l}\text { Cell growth reduction } \\
\text { Apoptosis }\end{array}$ & {$[181]$} \\
\hline $\begin{array}{l}\text { Catechin+Inositol } \\
\text { hexaphosphate }\end{array}$ & Pancreatic carcinoma & In vitro human cell lines & $\begin{array}{l}\text { Cell growth reduction } \\
\text { Apoptosis }\end{array}$ & {$[182]$} \\
\hline Catechin+dextran & Pancreatic ductal adenocarcinoma & In vitro human cell lines & Apoptosis & {$[183]$} \\
\hline \multirow{7}{*}{ Catechin } & Unspecific solid tumors & Epidemiological studies & Green tea may have ingredients that may prevent cancer & {$[184]$} \\
\hline & Cervical carcinoma & Epidemiological studies & Undisclosed results & {$[185]$} \\
\hline & Esophageal carcinoma & Epidemiological studies & Ongoing & {$[186]$} \\
\hline & Bladder carcinoma & Epidemiological studies & $\begin{array}{l}\text { Green tea may have ingredients that slow the growth of } \\
\text { certain cancers }\end{array}$ & {$[187]$} \\
\hline & \multirow[b]{2}{*}{ Prostate carcinoma } & Epidemiological studies & Undisclosed results & {$[188]$} \\
\hline & & Epidemiological studies & $\begin{array}{l}\text { Green tea contains ingredients that may prevent or slow } \\
\text { the growth of this cancer }\end{array}$ & {$[189]$} \\
\hline & Colorectal carcinoma & Epidemiological studies & Ongoing & {$[190]$} \\
\hline $\begin{array}{l}\text { Epigallocatechin-3- } \\
\text { gallate }\end{array}$ & Leukemia & In vitro human cell lines & $\begin{array}{l}\text { Proliferation suppression } \\
\text { Cell diferentiation }\end{array}$ & {$[191]$} \\
\hline \multirow{2}{*}{$\begin{array}{l}\text { Epigallocatechin-3- } \\
\text { gallate }\end{array}$} & Hepatoma & In vitro murine cell lines & $\begin{array}{l}\text { Apoptosis } \\
\text { Phosphorylation of ElF2 } \alpha\end{array}$ & {$[192]$} \\
\hline & Melanoma & In vitro human cell lines & $\begin{array}{l}\text { Downregulation of inflamasommes } \\
\text { Mechanism of action }\end{array}$ & {$[193]$} \\
\hline $\begin{array}{l}\text { (-) Epigallocatechin-3- } \\
\text { gallate monoesters }\end{array}$ & Colorectal carcinoma & In vitro human cell lines & $\begin{array}{l}\text { Inhibition of cell proliferation Apoptosis induction } \\
\text { Reduction in hydrogen peroxide production }\end{array}$ & {$[194]$} \\
\hline \multirow{3}{*}{$\begin{array}{l}\text { Epigallocatechin-3- } \\
\text { gallate }\end{array}$} & Metachronous adenomas of the colorectum & Epidemiological studies & Ongoing & {$[196]$} \\
\hline & Breast carcinoma & Epidemiological studies & Ongoing & {$[197]$} \\
\hline & Lung carcinoma & Epidemiological studies & Ongoing & [198] \\
\hline
\end{tabular}

regulator of translation initiation) [192]. Ellis et al. [193] uncovered the underlying EGCG-induced melanoma inhibition mechanism by using EGCG against melanoma cancer cell lines. According to these authors, the downregulation of inflamasommes (multiprotein oligomer) decreases the secretion of IL-1 $\beta$ (a cytokine) which in turn decreases the activity of NF-kB that finally reduces cell growth. (-) Epigallocatechin-3-gallate monoesters (EGCG-C4, EGCG-C8 and EGCG-C16) were synthesized by Matsumura et al. [194] in order to overcome the poor stability of EGCG. In vitro studies pointed out a better stability for EGCG-C16 by inhibiting cell proliferation, inducing apoptosis and less production of hydrogen peroxide against colorectal carcinoma. Likewise, in murine models this compound was the most potent in tumor reduction. The undeniable contribution of EGCG has been gathered and reviewed by Singh et al. [195] describing that EGCG could fight cancer through various mechanisms, namely an antioxidant potential, induction of apoptosis and cell cycle arrest, effect against phase I and II enzymes, modulation of intracellular signaling cascades, inhibition of epigenetic modifications, inhibition of dihydrofolate reductase and telomerase, inhibition of angiogenesis, modification of miRNA expression and other miscellaneous mechanisms. The chemopreventive and anticancer effects of epigallocatechin-3-gallate have also been assessed through clinical trials, against metachronous adenomas of the colorectum, breast and small cell lung cancer [196-198].

\subsubsection{Isoflavones}

Genistein and daizedin are the major compounds of the isoflavones and have been described as having antitumor activity and sensitizing effects (Table 13). Genistein, the most common compound in soy has been tested against prostate cancer cell lines, and resulted in inhibition of cell proliferation in a dose dependent manner as well as upregulation of glutathione peroxidase and downregulation of apoptosis inhibitors and DNA topoisomerase [199]. Murine models have also been used to assess the effects of genistein. Wang et al. [200] attempted to describe the effects to lifetime exposure of different doses of genistein $(0,25$ and 250 $\mathrm{mm} / \mathrm{kg}$ body weight) in rats. These concentrations were given to rats for 11 months, after which they were injected with $\mathrm{N}$ methylnitrosourea to induce prostate cancer. The rats which had consumed the higher dosage of genistein had less prostate and other tumor incidence when compared to the control ones. Another remarkable effect of genistein is the capacity to sensitize tumors for other anticancer medication like gemcitabine and cisplatin, namely against pancreatic, ovarian and cervical cancers. In addition, it also potentiated the effects of TRAIL [201-205]. In 2008, Banerjee et al. [206], reviewed the in vitro targets of genistein in apoptosis, cell cycle arrest and transcription factors as well as the effects of angiogenesis, metastasis and sensitizing effects, based on previous studies. Two more reviews were published regarding the effect of genistein on cancer, revising the in vitro, in vivo and clinical trials in which this compound has been involved. Both indicate that despite the remarkable effect of this compound on in vitro and in vivo assays, clinical trials have failed to come up with standardized methods to test this compound, making it difficult to draw satisfactory conclusions and urging researchers to rethink and design common clinical trials for this natural compound [207, 208]. The clinical trials against cancer using genistein studied both the joint activity of genistein with other drugs (gemcitabine and 
Table 13. Isoflavones with reported antitumor activity.

\begin{tabular}{|c|c|c|c|c|}
\hline Compound & Type of Tumor & Type of Assay & Result Summary & Reference \\
\hline \multirow[t]{2}{*}{ Genistein } & \multirow[t]{2}{*}{ Prostate carcinoma } & In vitro human cell lines & $\begin{array}{l}\text { Proliferation inhibition } \\
\text { Downregulation of apoptosis inhibitor }\end{array}$ & {$[199]$} \\
\hline & & In vivo murine models & Less incidence of prostate cancer and other carcinomas & {$[200]$} \\
\hline \multirow[t]{2}{*}{ Genistein + Gemcitabine } & \multirow[t]{2}{*}{ Pancreatic carcinoma } & \multirow{2}{*}{$\begin{array}{l}\text { In vitro human cell lines } \\
\text { In vivo murine models }\end{array}$} & $\begin{array}{l}\text { Growth inhibition } \\
\text { Apoptosis }\end{array}$ & {$[206]$} \\
\hline & & & Downregulation of NF-kB & {$[202]$} \\
\hline \multirow[b]{2}{*}{ Genistein + Cisplatin } & Ovarian carcinoma & In vitro human cell lines & Inhibition of survivin & {$[203]$} \\
\hline & Cervical carcinoma & In vitro human cell lines & $\begin{array}{l}\text { Inhibition of NF-kB } \\
\text { Inhibition of } \mathrm{Akt} / \mathrm{mTOR} \text { pathways }\end{array}$ & {$[204]$} \\
\hline Genistein + TRAIL & Glioma & In vitro human cell lines & Facilitation of TRAIL-mediated apoptosis & {$[205]$} \\
\hline Genistein + Gemcitabine & Breast carcinoma & Epidemiological studies & Undisclosed results & {$[209]$} \\
\hline \multirow{2}{*}{ Genistein } & Bladder carcinoma & Epidemiological studies & Undisclosed results & {$[210]$} \\
\hline & Breast carcinoma & Epidemiological studies & Undisclosed results & {$[211]$} \\
\hline $\begin{array}{l}\text { Genistein }+ \text { Gemcitabine } \\
\text { Genistein + erlotinib }\end{array}$ & Pancreatic carcinoma & Epidemiological studies & Undisclosed results & {$[213]$} \\
\hline Genistein & \multirow{2}{*}{ Prostate carcinoma } & Epidemiological studies & Undisclosed results & {$[214]$} \\
\hline Genistein + Quercetin & & Epidemiological studies & Ongoing & {$[215]$} \\
\hline Genistein & Bladder carcinoma & Epidemiological studies & Ongoing & {$[216]$} \\
\hline Genistein + Gemcitabine & Lung carcinoma & Epidemiological studies & Ongoing & {$[217]$} \\
\hline Genistein + Interleukin-2 & $\begin{array}{l}\text { Melanoma } \\
\text { Kidney carcinoma }\end{array}$ & Epidemiological studies & Ongoing & {$[218]$} \\
\hline \multirow[t]{2}{*}{ Daidzein } & Breast carcinoma & In vitro human cell lines & $\begin{array}{l}\text { Cell proliferation inhibition } \\
\text { G1 and G2 phases arrest }\end{array}$ & {$[219]$} \\
\hline & Prostate carcinoma & In vitro human cell lines & Angiogenesis inhibition & {$[220]$} \\
\hline \multirow{3}{*}{ Daidzein } & Colon carcinoma & In vitro human cell lines & $\begin{array}{l}\text { Caspase- } 3 \text { activity increase } \\
\text { Cell growth inhibition }\end{array}$ & {$[221]$} \\
\hline & Breast carcinoma & In vivo murine models & $\begin{array}{l}\text { Tumor inhibition } \\
\text { Apoptosis }\end{array}$ & {$[222]$} \\
\hline & Mammary carcinoma & In vivo murine models & Reduction in tumor multiplicity, incidence, burden and latency & {$[223]$} \\
\hline
\end{tabular}

erlotinib) and the pharmacokinetics of this drug, along with the traditional trials against bladder, breast and pancreatic cancer [209213]. Currently, on-going clinical trials are studying genistein against prostate, bladder, lung and kidney cancers, as well as melanoma [214-218].

Daidzein has also been studied against cancer, but to a shorter extent when compared to genistein. It has shown in vitro activity against breast cancer by inhibiting proliferation in $\mathrm{G} 1$ and $\mathrm{G} 2$ phases and increase in caspase-9 activity [219]. Similar activity was detected both for prostate and colon cancer, this last one being one of the most common cancers in the world, with poor response too chemotherapeutic agents [220, 221]. Mammary human xenografts have also been sensitive do daidzein,with tumor inhibition and apoptosis described [222]. The preventive capacity of this compound was assessed by Constatinou et al. [223] by joining it with tamoxifen and administrating it to mice with induced mammary tumors. The authors concluded that this mixture reduced tumor multiplicity by $76 \%$, incidence by $35 \%$, tumor burden and latency by $95 \%$ and $62 \%$, respectively. These favorable results haven't been translated into extensive clinical trials.

\subsubsection{Flavanones}

The anticancer potential of flavanones hasn't been studied to the same extent as the other flavonoids, although some activity has been reported, especially on hesperidin and 2'-OH flavanone (Table 14). Itiogawa et al. [224] carried out a screening of 10 flavanones (Sophoraflavanone-B, Senegalensein, Amorilin, Euchrestaflavanone-A, Lupinifolin, Lupinifolinol, Paratocarpin-I,
Erythrisenegalone, Citflavanone and Yukovanol) against human Raji cells infected with Epstein-Barr virus (EBV). This virus is associated with a high risk of various cancers. All the flavanones exhibited inhibitory effect against the infected cells without showing toxicity towards the normal cells. Furthermore, in murine models, only lupinfolin showed tumor inhibition against the induced tumors. Another screening involving Raji cells infected with EBV and flavanones (Munduleaflavanone A, Prostratol $\mathrm{F}$ and 40-O-Geranylnaringenin among others) resulted in inhibition of infected cells proliferation in a dose dependent manner [225]. Hesperidin, one of the most studied flavanones has been described as an in vitro inhibitor of human nasopharyongeal carcinoma epithelial cells and mammary carcinoma cell lines by arresting cell growth, inducing apoptosis and expressing caspase-3 [226, 227]. Shen et al. [228], carried out in vitro and in vivo studies with 8 flavanones (2'-OH flavanone; 4'-OH flavanone; 6-OH flavanone; 7-OH flavanone; Naringenin; Nargin and Toxifolin) against various cell lines of human colon adenocarcinoma. The in vitro study pointed out excellent inhibition constants for 2'OH flavanone and apoptosis via caspase- 3 and very little toxicity towards sane cells. Murine models were used to induce colon adenocarcinoma, and after tumor growth, flavanones were administered. 2'-OH Flavanone was once again the compound with the highest inhibition rates by triggering apoptosis and increasing p21. A very similar study was carried out by Hsiao et al. [229] in 2007, where various flavanones were screened against human lung adenocarcinoma, Lewis lung adenocarcinoma, murine lung adenocarcinoma, human gastric epithelial adenocarcinoma and human hepatocellular 
adenocarcinoma. Once again the 2'-OH flavanone was the best inhibitor of all the cancer cell lines by arresting the cell cycle and promoting the reduction of cyclin $\mathrm{B}, \mathrm{D}$ and $\mathrm{Cdc} 2$ (proteins that control progression of cells through the cell cycle). The authors then tested this compound in nude mice with Lewis lung tumors. After 8 and 17 days, the mice treated with the flavanone displayed smaller tumors than the control group.

The authors are unaware of any finished or ongoing anticancer clinical trials using flavanones as drugs, this may be due to the little reports of in vitro and murine assays regarding this group of flavonoids. Although, as stated above there are some interesting results regarding hesperidin and 2'-OH flavanone; more studies regarding these compounds should be carried out.

\subsubsection{Anthocyanidins}

Various compounds of this family have also been thoroughly studied for anticancer properties (Table 15). Many of them have exerted chemotherapeutic properties both in vitro and in vivo.

Table 14. Flavanones with reported antitumor activity.

\begin{tabular}{|c|c|c|c|c|}
\hline Compound & Type of Tumor & Type of Assay & Result Summary & Reference \\
\hline $\begin{array}{l}\text { Sophoraflavanone-B Senegalensein } \\
\text { Amorilin Euchrestaflavanone-A Lupinifolin } \\
\text { Lupinifolinol Paratocarpin-I Erythrisenegalone Citflavanone } \\
\text { Yukovanol }\end{array}$ & Human Raji cell line & $\begin{array}{l}\text { In vitro human cell lines } \\
\text { In vivo murine models }\end{array}$ & EBV inhibitory effect & {$[224]$} \\
\hline $\begin{array}{l}\text { Munduleaflavanone A } \\
\text { Prostratol F } \\
\text { 40-O-Geranylnaringenin }\end{array}$ & Human Raji cell line & In vitro human cell lines & EBV inhibitory effect & {$[225]$} \\
\hline \multirow[b]{2}{*}{ Hesperidin } & Nasopharyngeal carcinoma & In vitro human cell lines & $\begin{array}{l}\text { Cell division inhibition } \\
\text { Apoptosis }\end{array}$ & {$[226]$} \\
\hline & Mammary carcinoma & In vitro human cell lines & $\begin{array}{l}\text { Acumulation of p } 53 \\
\text { Expression of caspase- } 3 \\
\text { Cell proliferation inhibition }\end{array}$ & {$[227]$} \\
\hline $\begin{array}{l}\text { 2'-OH flavanone } \\
\text { 4'-OH flavanone } \\
\text { 6-OH flavanone } \\
\text { 7-OH flavanone Naringenin } \\
\text { Nargin } \\
\text { Toxifolin }\end{array}$ & Colon carcinoma & $\begin{array}{l}\text { In vitro human cell lines } \\
\text { In vivo murine models }\end{array}$ & $\begin{array}{l}\text { Caspase- } 3 \text { induction } \\
\text { Apoptosis } \\
\text { Tumor growth inhibition }\end{array}$ & {$[228]$} \\
\hline $\begin{array}{l}\text { 2'-OH flavanone } \\
\text { 4'-OH flavanone } \\
\text { 6-OH flavanone } \\
\text { Naringin } \\
\text { Naringenin }\end{array}$ & $\begin{array}{l}\text { Lung carcinoma } \\
\text { Murine lung carcinoma } \\
\text { Gastric carcinoma } \\
\text { Hepatocellular carcinoma }\end{array}$ & $\begin{array}{l}\text { In vitro human cell lines } \\
\text { In vivo murine models }\end{array}$ & $\begin{array}{l}\text { Cell cycle arrest } \\
\text { Reduction of cyclin B, D and } \\
\text { Cdc2 } \\
\text { Tumor reduction }\end{array}$ & [229] \\
\hline Peonidine-3-glucoside & Lung carcinoma & In vitro human cell lines & $\begin{array}{l}\text { Mobility and invasion } \\
\text { reduction } \\
\text { Metalloproteinases reduction }\end{array}$ & {$[236]$} \\
\hline Cyanidin-3-glucoside & $\begin{array}{l}\text { Murine skin carcinoma } \\
\text { Human lung carcinoma }\end{array}$ & $\begin{array}{l}\text { In vitro human cell lines } \\
\text { In vivo murine models }\end{array}$ & $\begin{array}{l}\text { Inhibition of cell proliferation } \\
\text { Tumor size reduction } \\
\text { Metastasis inhibition }\end{array}$ & {$[237]$} \\
\hline
\end{tabular}

Table 15. Anthocyanidins with reported antitumor activity.

\begin{tabular}{|c|c|c|c|c|}
\hline Compound & Type of Tumor & Type of Assay & Result Summary & Reference \\
\hline Delphinidin & Prostate carcinoma & $\begin{array}{l}\text { In vitro human cell lines } \\
\text { In vivo murine models }\end{array}$ & $\begin{array}{l}\text { Cell growth inhibition } \\
\text { Caspase mediated apoptosis } \\
\text { Tumor size reduction }\end{array}$ & {$[230]$} \\
\hline Delphinidin-3-sabubioside & Leukemia & In vitro human cell lines & $\begin{array}{l}\text { Caspase }-3,-8 \text { and } 9 \text { activation } \\
\text { Apoptosis }\end{array}$ & {$[231]$} \\
\hline $\begin{array}{l}\text { Cyanidin-3-rutinoside } \\
\text { Cyanidin-3-glucoside }\end{array}$ & Lung carcinoma & In vitro human cell lines & Dose dependent inhibitory effect & {$[232]$} \\
\hline Glibenclamide & Gastric carcinoma & In vitro human cell lines & $\begin{array}{l}\text { Cell viability reduction } \\
\text { Apoptosis }\end{array}$ & [233] \\
\hline Cyanidin-3-O-glucoside & Gastric carcinoma & In vitro human cell lines & $\begin{array}{l}\text { Reduction of cell proliferation } \\
\text { Morphological changes }\end{array}$ & [234] \\
\hline $\begin{array}{l}\text { Delphinidin } \\
\text { Cyanidin }\end{array}$ & Colorectal carcinoma & In vitro human cell lines & $\begin{array}{l}\text { Generation of ROS } \\
\text { Inhibition of glutathione reductase }\end{array}$ & {$[235]$} \\
\hline Peonidine-3-glucoside & Lung carcinoma & In vitro human cell lines & $\begin{array}{l}\text { Mobility and invasion reduction } \\
\text { Metalloproteinases reduction }\end{array}$ & {$[236]$} \\
\hline Cyanidin-3-glucoside & $\begin{array}{l}\text { Murine skin carcinoma } \\
\text { Human lung carcinoma }\end{array}$ & $\begin{array}{l}\text { In vitro human cell lines } \\
\text { In vivo murine models }\end{array}$ & $\begin{array}{l}\text { Inhibition of cell proliferation } \\
\text { Tumor size reduction } \\
\text { Metastasis inhibition }\end{array}$ & {$[237]$} \\
\hline
\end{tabular}


Delphinidin demonstrated a caspase mediated inhibition of cell proliferation and apoptosis against prostate cancer cell lines [230] while its derivative, delphidin-3-sambubioside demonstrated a ROS (Reactive Oxygen Species) mediated apoptotic effect against leukemia cell lines as well as activation of caspase $-3,-8$ and -9 . [231]. Lyanin-3-rutinoside and cyaniding-3-glucoside exhibited a migration and invasion inhibition on lung carcinoma cell lines [232]. Glibenclamide was able to reduce cell viability while inducing apoptosis by ROS dependent JNK enzymes against in vitro human carcinoma [233]. Sun et al. [234] isolated cyaniding-3$O$-glucoside from Myrica rubra and tested it against 3 types of gastric carcinoma cell lines, resulting in reduction of cell proliferation, typical apoptosis morphological changes in dose dependent manners. Two studies published in 2010 proved the anticancer effect of delphinidin, cyaniding and peonidin-3glucoside against colorectal and lung carcinoma with satisfactory results [235, 236]. Ding et al. [237] in the first anticancer in vivo experiment with anthocyanidins used cyanidine-3-glucoside against human lung adenocarcinoma, displaying satisfactory results for the preliminary assays, with inhibition of cell proliferation and complete blockage of cell growth for $40 \mu \mathrm{M}$. The authors, inspired by the good results, later induced skin tumors in mice, using 12-O'tetradecanolyphorbol-13-acetate and subsequently treated them with cyaniding-3-glucoside which proved to reduce tumor size and inhibition of metastasis. Hafeez et al. [230] also conducted assays on murine models implanted with prostate cancer cells, which later developed into tumors. Delphinidin decreased the tumor size and reduced the expression of NF-kB/65 nuclear translocation and NF-kB DNA binding activity. Despite few results regarding anthocyanidins as chemotherapeutic compounds, the effectiveness is quite remarkable and further in vivo studies should be carried out. To this date, the authors are unaware of any clinical trials regarding anthocyanidins, possibly due to few results from in vivo experiments.

\section{CONCLUSION}

Mankind has come a long way in the fight against cancer. The improvement of many therapies allied to the development of new drugs and treatments have assured in some cases the treatment or cure for certain cancers and a longer life span of patients. Yet, the long battle is far from over, especially due to incorrect food habits from the populations, along with an increase in smoking and pollution. Cancer cases are expected to increase in the near future, posing a threat for people across the globe as well as for governments who will have to waste astronomical funds for treatments if effective ones are not uncovered.

In some cancer cases, synthetic drugs or surgery can eradicate the threat, but highly metastasizing and drug resistant strains keep escaping treatments. The toxicity of synthetic compounds is also difficult to overcome, eliminating promising drugs from eventual administration. Natural compounds, isolated from plants or synthesized in a laboratory can be administered to patients, usually without the side effects and toxicity of synthetic preparations. These compounds can even be added to chemical preparations to increase their effect or to display a sensitizing action. Some natural compounds have been administered with success and are case studies for further applications. One of the main problems with natural compounds is the high cost and delay of compound separation and isolation even before the biological activity being assessed [238], resulting in the waste of considerable amounts of money in compounds that will not have any activity. When the compound is finally isolated the first step to determine its anticancer properties is a screen against cell lines. This type of assay is not free of disadvantages; in fact, some authors report that cell cultures maintained in the same conditions may be altered over time, resulting in "thousands of misleading studies and potentially erroneous papers published" [239]. This phenomenon is transversal to all types of cell cultures, including the cancer cell lines.
The main preliminary study before anticancer compounds are trialed in humans, are murine models. Several considerations should be assessed before conclusions are drawn, namely on the species selected for the study, type of tumors, correct definition of the endpoints and an appropriate statistical evaluation of tumor growth [240]. These steps should not be overlooked in order to provide consistent data regarding the biological activity against specific tumors in further human trials. If a compound has proven satisfactory results in animal models it can then be tested on humans. Although this is the final step in terms of trials for a compound to be readily available for the public it is also the most complicated step. The fact that the trials are carried out in humans requires extra caution in ethics and a well-designed procedure (doses, duration of treatment, concentration, placebos) to eliminate variables that would interfere in the real outcome of the treatment, moreover, it can be difficult to gather specific patients that suffer from the same type of cancer to have enough statistical significance. With all these drawbacks and pitfalls in anticancer treatment is there any hope against cancer? In terms of classic treatments with synthetic compounds, the evolution of technology will bring better and more effective therapeutics, so yes there should be hope. The awareness of the scientific community about the limitations and improvement areas in cancer therapy will surely overcome today's limitations in the near future. Regarding natural compounds, namely phenolic compounds, and considering that only $20 \%$ of the world's plants have been investigated [241] it is legitimate to think that many more compounds will be discovered, and in those compounds, many anticancer molecules could be found. Hope can also come from other matrixes, like mushrooms, microbes and marine organisms which are now targets of intense research for chemopreventive and chemotherapeutic anticancer molecules [242, 243].

Attending to the expected growing cases of cancer cases, research around this topic is also expected to increase, both on the mechanisms of cancer development and consequent methods to treat it. Funding for cancer research should be taken seriously, in order to reduce costs of treatments, patient suffering and mortality statistics. Mankind has come a long way in cancer therapy, but the road ahead is still full of challenges and opportunities.

\section{CONFLICT OF INTEREST}

The authors declare that they have no conflict of interest regarding this manuscript.

\section{ACKNOWLEDGEMENTS}

The authors are grateful to Fundação para a Ciência e a Tecnologia (FCT, Portugal) and COMPETE/QREN/EU for research project PTDC/AGR-ALI/110062/2009 and to CIMO (strategic project PEst-OE/AGR/UI0690/2011).

\section{REFERENCES}

[1] Jemal, A.; Bray, F.; Center, M.M.; Ferlay, J.; Ward, E.; Forman, D Global cancer statistics. CA. Cancer J. Clin., 2011, 61, 69-90.

[2] Schottenfeld, D.; Jr, J.F.F. Cancer epidemiology and prevention 3rd ed.; Oxford University Press: New York, 2006.

[3] Foo, J.; Michor, F. Evolution of resistance to anti-cancer therapy during general dosing schedules. J. Theor. Biol., 2010, 263, 179188.

[4] Rocha, A.B.; Lopes, R.M.; Schwartsman, G. Natural products in anticancer therapy. Curr. Opin. Pharmacol., 2001, 1, 364-369.

[5] Gordaliza, M. Natural products as leads to anticancer drugs. Clin. Trans. Oncol., 2007, 9, 767-776.

[6] Bougard, F.; Gravot, A.; Milesi, S.; Gontier, E. Production of plant secondary metabolites: a historical perspective. Plant Sci., 2001, 161, 839-851.

[7] Crozier, A.; Clifford, M.N.; Ashihara, H. Plant secondary metabolites: occurrence, structure and role in the human diet; Blackwell Publishing: Oxford, 2006. 
[8] Walton, N.J.; Brown, D.E. Chemicals from plants: perspectives on plant secondary products; Imperial College Press: London, 1999.

[9] Tansey, T.R.; Shechter, I. Structure and regulation of mammalian squalene synthase. Biochim. Biophys. Acta, 2000, 1529, 49-62.

[10] Dewick, P.M.; Medicinal natural products: a biosynthetic approach $2^{\text {nd }}$ ed.; John Wiley \& Sons: West Sussex, 2002.

[11] Moss, G.P. Nomenclature of steroids. Pure Appl. Chem., 1989, 61, 1783-1822.

[12] Roberts, M.F. Alkaloids: biochemistry, ecology and medicinal applications; Plenum Press: New York, 1998.

[13] Fraga, G.C.; Plant phenolics and human health: Biochemistry, nutrition and pharmacology; John Whiley \& Sons: New Jersey, 2010.

[14] Boudet, A. Evolution and current status of research in phenolic compounds. Phytochem., 2007, 68, 2722-2735.

[15] Lule, S.U.; Xia, W. Food phenolics, pros and cons: A review. Food Rev. Int., 2005, 21, 367-288.

[16] Dey, P.M.; Harborne, J.B. Plant biochemistry; Academic Press: California, 1997.

[17] Chung, K.; Wong, T.Y.; Wei, C.; Huang, Y.; Lin, Y. Tannins and human health: A review. Crit. Rev. Food Sci., 1998, 38, 421-464.

[18] Lüttge, U.; Beyschlag, W.; Büdel, B.; Francis, D. Progress in botany 72; Springer-Verlag: Heidelberg, 2011.

[19] Spencer, J.P.E. Flavonoids and related compounds: Bioavailability and function; CRC Press: Florida, 2012.

[20] Kalili, K.M.; Villiers, A. Recent development in the HPLC separation of phenolic compounds. J. Sep. Sci., 2011, 34, 854-876.

[21] Seigler, D.S. Plant secondary metabolism. Kluwer Academic Press, Massachussets: USA, 1998.

[22] Demirkiran, O. Xanthones in Hypericum: synthesis and biological activities. Top. Heterocycl. Chem., 2007, 9, 139-178.

[23] Nowakowska, Z. A review of the anti-infective and antiinflammatory chalcones. Eur. J. Med. Chem., 2007, 42, 125-137.

[24] Hopkins, W.G.; Hüner, N.P.A. Introduction to plant physiology. John Wiley \& Sons, Inc.: New York, USA, 2004.

[25] Buranov, A. U.; Mazza, G. Lignin in straw of herbaceous crops. Ind. Crop. Prod., 2008, 28, 237-259.

[26] Yang, X.; Zhang, P.; Hu, L.; Zhang, M.; Liu, C.; Liu, H.; Zhou, Y. Synthesis and bioactivity evaluation of lignin related high-addedvalue 1,4-dihydropyridines and polyhydroacridines. Ind. Crop. Prod., 2012, 38, 14-20.

[27] Sakagami, H.; Hashimoto, K.; Suzuki, F.; Ogiwara, T.; Satoh, K.; Ito, H.; Hatano, T.; Takashi, Y.; Fujisawa, S. Molecular requirements of lignin-carbohydrate complexes for expression of unique biological activities. Phytochem., 2005, 66, 2108-2120.

[28] Ayres, D.C.; Loike, J.D. Lignans: chemical, biological and clinical properties. Cambridge University Press: New York, USA, 1990.

[29] Topcu, G.; Demirkiran, O. Lignans from Taxus species. Top. Heterocycl. Chem., 2007, 11, 103-144.

[30] Lobo, A.M.; Lourenço, A.M. Biossíntese de produtos naturais; IST Press: Lisbon, 2007.

[31] Havsteen, B.H. The biochemistry and medical significance of the flavonoids. Farmacol. Therapeut., 2002, 96, 67-202.

[32] Aherne, S.A.; O’Brien, N.M. Dietary flavonols: chemistry, food content and metabolism. Nutrition, 2002, 18, 75-81.

[33] Si, D.; Wang, Y.; Zhou, Y.; Guo, Y.; Wang, J.; Zhou, H.; Li, Z.; Fawcett, J.P. Mechanism of $\mathrm{CYP}_{2} \mathrm{C}_{9}$ inhibition by flavones and flavonols. Drug Metab. Dispos., 2009, 37, 629-634.

[34] Martens, S.; Mithöfer, A. Flavones and flavone synthases. Phytochem., 2005, 66, 2399-2407.

[35] Aron, P.M.; Kennedy, J.A. Flavan-3-ols: nature, occurrence and biological activity. Mol. Nutr. Food Res., 2008, 52, 79-104.

[36] Andres, A.; Donovan, S.M.; Kuhlenschmidt, M.S. Soy isoflavones and virus infections. J. Nutr. Biochem., 2009, 20, 563-569.

[37] Messina, M.; Bennink, M. 10 Soyfoods, isoflavones and risk of colonic cancer: a review of the in vitro and in vivo data. Bailliere Clin. Endoc., 1998, 12, 707-728.

[38] Rostango, M.A.; Villares, A.; Guillamón, E.; García-Lafuente, A.; Martínez, J.A. Sample preparation for the analysis of isolflavones from soybeans and soy foods. J. Cromatogr. A, 2009, 1216, 2-29.

[39] Lanham-New, S.A.; Macdonald, I.A.; Roche, H.M. Nutrition and metabolism $2^{\text {nd }}$ ed; John Wiley \& Sons, West Sussex, 2011.
[40] Shi, L.; Feng, X.E.; Cui, J.R.; Fang, L.H.; Du, G.H.; Li, Q. S. Synthesis and biological activity of flavanone derivatives. Bioorg. Med. Chem. Lett., 2010, 20, 5466-5468.

[41] Tomás-Barberán, F.A.; Clifford, M.N. Flavanones, chalcones, and dihydrochalcones-nature, occurrence and dietary burden. J. Sci. Food Agric., 2000, 80, 1073-1080.

[42] Gould, K.; Davies, K.; Winefield C. Anthocyanins: biosynthesis, functions and applications; SpringerScience+Business Media, New York, 2009.

[43] Schofield, P.; Mbugua, D.M.; Pell, A.N. Analysis of condensed tannins: A review. Anim. Feed Sci. Technol., 2001, 91, 21-40.

[44] Castañeda-Ovando, A.; Pacheco-Hernández, M.L.; PáezHernández, M.E.; Rodríguez, J.A., Galán-Vidal, C.A. Chemical studies of anthocyanins: a review. Food Chem., 2009, 113, 859871.

[45] Lila, M.A. Anthocyanins and human health: an in vitro investigative approach. J. Biomed. Biotechnol., 2004, 2004, 306313.

[46] Carocho, M.; Ferreira, I.C.F.R. A review on antioxidants, prooxidants and related controversy: natural and synthetic compounds, screening and analysis methodologies and future perspectives. Food Chem. Toxicol., 2013, 51, 15-25.

[47] Anand, P.; KunnumakaraB.; Sundaram, C.; Harikumar, K.B.; Tharakan, S.T.; Lai, O.S.; Sung, B.; Aggarwal, B.B. Cancer is a preventable disease that requires major lifestyle changes. Pharm. Res., 2008, 25, 2097-2116.

[48] Pan L.; Chai, H.; Kinghorn, A.D. The continuing search for antitumor agents from higher plants. Phytochem. Lett., 2010, 3, 1-8.

[49] Meng, X.; Zhong, J.; Liu, S.; Murray, M; Gonzalez-Angulo, A.M. A new hypothesis for the cancer mechanism. Cancer Metastasis Rev., 2012, 31, 247-268.

[50] Becsei-Kilborn, E. Scientific discovery and scientific reputation: The reception of Peyton Rous' discovery of the chicken sarcoma virus. J. Hist. Biol., 2010, 43, 111-157.

[51] Sarid, R.; Gao, S. Viruses and human cancer: from detection to causality. Cancer Lett., 2011, 305, 218-227.

[52] Vähä-Koskela, M.J.V.; Heikkilä, J.E.; Hinkkanen, A.E. Oncolytic viruses in cancer therapy. Cancer Lett., 2007, 254, 178-216.

[53] Calin, G.A.; Croce, C.M. MicroRNAs and chromosomal abnormalities in cancer cells. Oncogene, 2006, 25, 6202-6210.

[54] Mitelman, F. Recurrent chromosome aberrations in cancer. Mutat. Res., 2000, 462, 247-253.

[55] Soto, A.M.; Sonnenschein, C. The somatic mutation theory of cancer: growing problems with the paradigm? Bioessays, 2004, 26, 1097-1107.

[56] Frank, S.A.; Nowak, M.A. Problems of somatic mutation and cancer. Bioessays, 2004, 26, 291-299.

[57] Loeb, L.A.; Loeb, K.R.; Anderson, J.P. Multiple mutation in cancer. Proc. Natl. Acad. Sci., 2003, 776-781.

[58] Brunet, M. Cancer - a biological approach. Br. Med. J., 1957, 1, 841-847.

[59] Thomas, L. Cellular and humoral aspects of the hypersensitive states. Heober-Harper, New York, 1957.

[60] Dunn, G.P.; Bruce, A.T.; Ikeda, H.; Old, L.J.; Schrieber, R.D. Cancer immunoediting: from immuno-surveillance to tumor escape. Nat. Immunol., 2002, 3, 991-998.

[61] Kim, R.; Emi, M.; Tanabe, K. Cancer immunoediting from imune surveillance to imune escape. Immunology, 2007, 121, 1-14.

[62] Haddow, A. Molecular repair, wound healing and carcinogenesis: Tumor production a possible overhealing? Adv. Cancer Res., 1972, $16,181-234$.

[63] Dvorak, H. Tumors: Wounds that do not heal: similarities between tumor stroma generation and wound healing. N. Engl. J. Med., 1986, 315, 1650-1659.

[64] Riss, J.; Khanna, C.; Koo, S.; Chandramouli, G.V.R.; Yang, H.H.; Hu, Y.; Kleiner, D.E.; Rosenwald, A.; Schaefer, C.F.; Ben-Sasson, S.A.; Yang, L.; Powell, J.; Kane, D.W.; Star, R.A.; Aprelikova, O.; Bauer, K.; Vasselli, J.R.; Maranchi, J.K.; Kohn, K.W.; Buetow, K.H.; Linehan, W.M.; Weinstein, J.N.; Lee, M.P.; Klausner, R.D.; Barret, J.C. Cancers as wounds that do not heal: differences and similarities between renal regeneration/repair and renal cell carcinoma. Cancer Res., 2006, 66, 7216-7224. 
[65] Cunningham, M.L. Role of increased DNA replication in the carcinogenic risk of nonmutagenic chemical carcinogens. Mutat. Res., 1996, 365, 59-69.

[66] Tennant, R.W. A perspective on nonmutagenic mechanisms in carcinogenesis. Environ. Health Persp., 1993, 101, 231-236.

[67] Sonnenschein, C.; Soto, A.M. Theories of carcinogenesis: an emerging perspective. Semin. Cancer. Biol., 2008, 18, 372-377.

[68] Sonnenschein, C.; Soto, A.M. Somatic mutation theory of carcinogenesis: why it should be dropped and replaced. Mol. Carcinog., 2000, 29, 205-211.

[69] Cao, Y.; Cao, R.; Bråkenhielm, E. Antiangiogenic mechanisms of diet-derived polyphenols. J. Nutr. Biochem., 2002, 13, 380-390.

[70] Madlener, S.; Illmer, C.; Horvath, Z.; Saiko, P.; Losert, A.; Herbacek, I.; Grusch, M.; Elford, H.L.; Krupitza, G.; Bernhaus, A.; Fritzer-Szekeres, M.; Szekeres, T. Gallic acid inhibits ribonucleotide reductase and cyclooxygenases in human HL-60 promyelocytic leukemia cells. Cancer Lett., 2007, 245, 156-162.

[71] Reddy, T.C.; Reddy, D.B.; Aparna, A.; Arunasree, K.M.; Gupta, G.; Achari, C.; Reddy, G.V.; Lakshmipathi, V.; Subramanyam, A.; Reddanna, P. Anti-leukemic effects of gallic acid on human leukemia K562 cells: downregulation of COX-2, inhibition of $\mathrm{BCR} / \mathrm{ABL}$ kinase and NF-kB inactivation. Toxicol. In Vitro, 2012, 26, 396-405.

[72] Lu, Y.; Jiang, F.; Jiang, H.; Wu, K.; Zheng, X.; Cai, Y.; Katakowski, M.; Chopp, M.; To, S.T. Gallic acid suppresses cell viability, proliferation, invasion and angiogenesis in human glioma cells. Eur. J. Pharmacol., 2010, 641, 102-107.

[73] Ji, B.; Hsu, W.; Yang, J.; Hsia, T.; Lu, C.; Chiang, J.; Yang, J.; Lin, C.; Lin, J.; Suen, L.; Wood, W.G.; Chung, J. Gallic acid induces apoptosis via caspase-3 and mitochondrion-dependent pathways in vitro and suppresses lung xenograft tumor growth in vivo. J. Agric. Food Chem., 2009, 57, 7596-7604.

[74] Umesalma, S.; Sudhandiran, G. Ellagic acid prevents rat colon carcinogenesis induced by 1,2 dimethyl hydrazine through inhibition of AKT-phosphoinositide-3 kinase pathway. Eur. J. Pharmacol., 2011, 660, 249-258.

[75] Kim, S.; Gaber, M.W.; Zawaski, J.A.; Zhang, F.; Richardson, M.; Zhang, X.A.; Yang, Y. The inhibition of glioma growth in vitro and in vivo by a chitosan/ellagic acid composite biomaterial. Biomaterials, 2009, 30, 4743-4751.

[76] Alias, L.M.; Manoharan, S.; Vellaichammy, L.; Balakrishnan, S.; Ramachandran, C.R. Protective effect of Ferulic acid on 7,12dimethylbenz[a]anthracene-induced skin carcinogenesis in Swiss albino mice. Exp. Toxicol. Pathol., 2009, 61, 205-2014.

[77] Baskaran, N.; Manoharan, S.; Balakrishnan, S.; Pugalendhi, P. Chemopreventive potential of ferulic acid in 7,12-dimethylbenz[a] anthracene-induced mammary carcinogenesis in Sprague-Dawley rats. Eur. J. Pharmacol., 2010, 637, 22-29.

[78] Wang, C.; Chen, L.; Yang, L. Cuphiin D1, the macrocyclic hydrolyzable tannin induced apoptosis in HL-60 cell line. Cancer Lett., 2000, 149, 77-83.

[79] Miyamoto, K.; Nomura, M.; Sasakura, M.; Matsui, E.; Koshiura, R.; Murayama, T.; Furukawa, T.; Hatano, T.; Yoshida, T.; Okuda, T. Antitumor activity of oenothein B, a unique macrocyclic ellagitannin. Jpn. J. Cancer Res., 1993, 84, 99-103.

[80] Wang, C.; Chen, L.; Yang, L. Antitumor activity of four macrocyclic ellagitannins from Cuphea hyssopifolia. Cancer Lett., 1999, 140, 195-200.

[81] Chen, J.; Shao, Y.; Huang, M.; Chin, C.; Ho, C. Inhibitory effect of caffeic acid phenethyl ester on human leukemia HL-60 cells. Cancer Lett., 1996, 108, 211-214.

[82] Kuo, H.; Kuo, W.; Lee, Y.; Lin, W.; Chou, F.; Tseng, T. Inhibitory effect of caffeic acid phenethyl ester on the growth of C6 glioma cells in vitro and in vivo. Cancer Lett., 2006, 234, 199-208.

[83] Lee, Y.; Kuo, H.; Chu, C.; Wang, C.; Lin, W.; Tseng, T. Involvement of tumor suppressor protein p53 and p38 MAPK in caffeic acid phenethyl ester-induced apoptosis of C6 glioma cells. Biochem. Pharmacol., 2003, 66, 2281-2289.

[84] Lin, W.; Liang, W.; Lee, Y.; Chuang, S.; Tseng, T. Antitumor progression potential of caffeic acid phenethyl ester involving p75 ${ }^{\mathrm{NTR}}$ in C6 glioma cells. Chem. Biol. Interact., 2010, 188, 607-615.

[85] Ekmekcioglu, C.; Feyertag, J.; Marktl, W. Cinnamic acid inhibits proliferation and modulates brush border membrane enzyme activities in Caco-2 cells. Cancer Lett., 1998, 128, 137-144.
[86] Akao, Y.; Maruyama, H.; Matsumoto, K.; Ohguchi, K.; Nishizawa, K.; Sakamoto, T.; Araki, Y.; Mishima, S.; Nozawa, Y. Cell growth inhibitory effect of cinnamic acid derivatives from propolis on human tumor cell lines. Biol. Pharm. Bull., 2003, 26, 1057-1059.

[87] Revill, P.; Mealy, N.; Serradell.; Bolos, J.; Rosa, E. Panobinostat Drugs Fut., 2007, 32, 315-322.

[88] Ellis, L.; Pan, Y.; Smyth, G.K.; George, D.J.; McCormack, C.; Williams-Truax, R.; Mita, M.; Beck, J.; Burris, H.; Ryan, G.; Atadja, P.; Butterfoss, D.; Dugan, M.; Culver, K.; Johnstone, R.W.; Prince, H.M. Histone deacetylase inhibitor Panobinostat induces clinical responses with associated alterations in gene expression profiles in cutaneous T-cell lymphoma. Clin. Cancer Res., 2008, $14,4500-4510$.

[89] University of Utah; Novartis Pharmaceuticals. Pharmacokinetics and safety of Panobinostat in patients with advanced solid tumors and various degrees of hepatic function. In: Clinicaltrials.gov [Internet] 2009. [Cited 2012 Oct. 17] Available from: http:// clinicaltrials.gov/ct2/show/study/NCT01007968?term=Cinnamic + a cid\&rank=1 NLM Identifier: NCT01007968

[90] Devji, T.; Reddy, C.; Woo, C.; Awale, S.; Kadota, S.; Carrico-Moniz, D. Pancreatic anticancer activity of a novel geranylgeranylated coumarin derivative. Bioorg. Med. Chem. Lett., 2011, 21, 5770-5773.

[91] Lopez-Gonzalez, J.S.; Prado-Garcia, H.; Aguilar-Cazares, D.; Molina-Guarneros, J.A.; Morales-Fuentes, J.; Mandoki, J.J. Apoptosis and cell cycle disturbances induced by coumarin and 7hydroxycoumarin on human lung carcinoma cell lines. Lung Cancer, 2004, 43, 275-283.

[92] Jung, J.; Lee, J.; Oh, S.; Lee, J.; Park, O. Synthesis and antitumor activity of 4-hydroxycoumarin derivatives. Bioorg. Med. Chem. Lett., 2004, 14, 5527-5531.

[93] Bronikowska, J.; Szliszka, E.; Jaworska, D.; Czuba, Z.P.; Krol, W. The coumarin psoralidin enhances anticancer effect of tumor necrosis factor-related apoptosis-inducing ligand (TRAIL). Molecules, 2012, 17, 6449-6464.

[94] Finn, G.J.; Creaven, B.S.; Egan, D.A. Daphnetin induced differentiation of human renal carcinoma cells and its mediation by p38 mitogen-activated protein kinase. Biochem. Farmacol., 2004, 67, 1779-1788.

[95] Watanabe, J.; Nishiyama, H.; Matsui, Y.; Ito, M.; Kawanishi, H.; Kamoto, T.; Ogawa, O. Dicoumarol potentiates cisplatin-induced apoptosis mediated by c-Jun N-terminal kinase in p53wild-type urogenital cancer cell lines. Oncogene, 2006, 25, 2500-2508.

[96] Matsui, Y.; Watanabe, J.; Ding, S.; Nishizawa, K.; Kajita, Y.; Ichioka, K.; Saito, R.; Kobayashi, T.; Ogawa, O.; Nishiyama, Y. Dicoumarol enhances doxorubicin-induced cytotoxicity in p53 wild-type urothelial cancer cells through p38 activation. BJU Intern., 2010, 105, 558-564.

[97] Yang, J.; Xiao, Y.; He, X.; Qiu, G.; Hu, X. Aesculetin-induced apoptosis through a ROS-mediated mitochondrial dysfunction pathway in human cervical cancer cells. J. Asian Nat. Prod. Res., 2010, 12, 185-193.

[98] Thati, B.; Noble, A.; Creaven, B.S.; Walsh, M.; Kavanagh, K.; Egan, D.A. An in vitro investigation of the induction of apoptosis and modulation of cell cycle events in human cancer cells by bisphenanthroline-coumarin-6,7-dioxacetatocopper(II) complex. Chem. Biol. Interact., 2007, 168, 143-158.

[99] Lake, B.G. Coumarin metabolism, toxicity and carcinogenicity: relevance for human risk assessment. Food Chem. Toxicol., 1999, 37, 423-453.

[100] Marshall, M.E.; Mendelsohn, L.; Butler, K.; Riley, L.; Cantrell, J.; Wiseman, C.; Taylor, R.; Macdonald, J.S. Treatment of metastatic renal cell carcinoma with coumarin (1,2-benzopyrone) and cimetidine: a pilot study. J. Clin. Oncol., 1987, 5, 862-866.

[101] Nolte, H.; Pedersen, L.; Mouridsen, H.T. Combined treatment of advanced malignant melanoma with coumarin and cimetidine. Anticancer Res., 1987, 7, 449-450.

[102] Jonsson Comprehensive Cancer Center; National Cancer Institute. Warfarin and Vatalanib in treating patients with advanced solid tumors. In: Clinicaltrials.gov [Internet] 2004. [Cited 2012 Dec. 1] Available from: http://www.clinicaltrials.gov/ct2/show/NCT00091299? term=warfarin+cancer\&rank=2 NLM Identifier: NCT00091299

[103] Matsumoto, K.; Akao, Y.; Ohguchi, K.; Ito, T.; Tanaka, T.; Iinuma, M.; Nozawa, Y. Xanthones induce cell-cycle arrest and apoptosis 
in human colon cancer DLD-1 cells. Bioorg. Med. Chem., 2005, 13, 6064-6069.

[104] Nakagawa, Y.; IInuma, M.; Naoe, T.; Nozawa, Y.; Akao, Y. Characterized mechanism of a-mangostin-induced cell death: caspase-independent apoptosis with release of endonuclease-G from mitochondria and increased miR-143 expression in human colorectal cancer DLD-1 cells. Bioorg. Med. Chem., 2007, 15, $5620-5628$.

[105] Akao, Y.; Nakagawa, Y.; Iinuma, M.; Nozawa, Y. Anti-cancer effects of xanthones from pericarps of mangosteen. Int. J. Mol. Sci., 2008, 9, 355-370.

[106] Matsumoto, K.; Akao, Y.; Yi, H.; Ohguchi, K.; Ito, T.; Tanaka, T.; Kobayashi, E.; Iinuma, M.; Nozawa, Y. Preferential target is mitochondria in a-mangostin-induced apoptosis in human leukemia HL60 cells. Bioorg. Med. Chem., 2004, 12, 5799-5806.

[107] Wang, J.J.; Sanderson, B.J.S.; Zhang, W. Cytotoxic effect of xanthones from pericarp of the tropical fruit mangosteen (Garcinia mangostana Linn.) on human melanoma cells. Food Chem. Toxicol., 2011, 49, 2385-2391.

[108] Kaomongkolgit, R.; Chaisomboon, N.; Pavasant, P. Apoptotic effect of alpha-mangostin on head and neck squamous carcinoma cells. Arch. Oral Biol., 2011, 56, 483, 490.

[109] Chao, A.; Hsu, Y.; Liu, C.; Kuo, P. $\alpha$-mangostin, a dietary xanthone, induces autophagic cell death by activating the AMPactivated protein kinase pathway in glioblastoma cells. J. Agric. Food Chem., 2011, 59, 2086-2096.

[110] Shan, T.; Ma, Q.; Guo, K.; Liu, J.; Li, W.; Wang, F.; Wu, E. Xanthones from mangosteen extracts as natural chemopreventive agents: potential anticancer drugs. Curr. Mol. Med., 2011, 11, 666677.

[111] Ho, C.; Huang, Y.; Chen, C. Garcinone E, a xanthone derivative, has potent cytotoxic effect against hepatocellular carcinoma cell lines. Planta Med., 2002, 68, 975-979.

[112] Hahnvajanawong, C.; Boonyanugomol, W.; Nasomyon, T.; Loilome, W.; Namwat, N.; Anantachoke, N.; Tassaneeyakul, W.; Sripa, B.; Namwat, W.; Reutrakul, V. Apoptotic activity of caged xanthones from Garcinia hanburyi in cholangiocarcinoma cell lines. World J. Gastroenterol., 2010, 16, 2235-2243.

[113] Na, Y. Recent cancer drug development with xanthone structures. J. Pharm. Pharmacol., 2009, 61, 707-712.

[114] Korobi, M.; Shinmoto, H.; Tsushida, T.; Shinohara, K. Phloretininduced apoptosis in B 16 melanoma 4A5 cells by inhibition of glucose transmembrane transport. Cancer Lett., 1997, 19, 207-212.

[115] Yang, K.; Tsai, C.; Wang, Y.; Wei, P.; Lee, C.; Chen, J.; Wu, C.; Ho, Y. Apple polyphenol phloretin potentiates the anticancer actions of Paclitaxel through induction of apoptosis in human Hep G2 cells. Mol. Carcinog., 2009, 48, 420-431.

[116] Cheng, S.; Liu, R.H.; Sheu, J.; Chen, S.; Sinchaikul, S.; Tsay, G.J. Toxicogenomics of A375 human malignant melanoma cells treated with arbutin. J. Biomed. Sci., 2007, 14, 87-105.

[117] Szliszka, E.; Czuba, Z.P.; Mazur, B.; Paradysz, A.; Krol, W. Chalcones and dihydrochalcones augment TRAIL-mediated apoptosis in prostate cancer cells. Molecules, 2010, 15, 5336-5353.

[118] Anto, R.J.; Sukumaran, K.; Kuttan, G.; Rao, M.N.A.; Subbaraju, V.; Kuttan, R. Anticancer and antioxidant activity of synthetic chalcones and related compounds. Cancer Lett., 1995, 97, 33-37.

[119] Boumendjel, A.; Boccard, J.; Carrupt, P.; Nicolle, E.; Blanc, M.; Geze, A.; Choisnard, L.; Wouessidjewe, D.; Matera, E.; Dumontet, C. Antimitotic and antiproliferative activities of chalcones: forward structure-activity relationship. J. Med. Chem., 2008, 51, 23072310.

[120] Kumar, D.; Kuman, N.M.; Akamatsu, K.; Kusaka, E.; Harada, H.; Ito, T. Synthesis and biological evaluation of indolyl chalcones as antitumor agents. Bioorg. Med. Chem. Lett., 2010, 20, 3916-3919.

[121] Mohamed, M.F.; Mohamed, M.S.; Shouman, S.A.; Fathi, M.M.; Abdelhamid, I.A. Synthesis and biological evaluation of a novel series of chalcones incorporated pyrazole moiety as anticancer and antimicrobial agents. Appl. Biochem. Biotechnol., 2012, 168, 11531162.

[122] Orlikova, B.; Tasdemir, D.; Golais, F.; Dicato, M.; Diederich, M. Dietary chalcones with chemopreventive and chemotherapeutic potential. Genes Nutr., 2011, 6, 125-147.

[123] Jang, M.; Cai, L.; Udeani, G.O.; Slowing, K.V.; Thomas, C.F.; Beecher, C.W.W.; Fong, H.H.S.; Farnsworth, N.R.; Kinghorn,
A.D.; Mehta, R.G.; Moon, R.C.; Pezzuto, J.M. Cancer chemopreventive activity of resveratrol, a natural product derived from grapes. Science, 1997, 275, 218-220.

[124] Hagiwara, K.; Kosaka, N.; Yoshioka, Y.; Takahashi, R.; Takeshita, F.; Ochiya, T. Stilbene derivatives promote Ago2-dependent tumour-suppressive microRNA activity. Sci. Rep., 2012, 2, doi:10.1038/srep00314

[125] Simoni, D.; Roberti, M.; Invidiata, F.P.; Aiello, E.; Aiello, S.; Marchetti, P.; Baruchello, R.; Eleopra, M.; Cristina, A.D.; Grimaudo, S.; Gebbia, N.; Crosta, L.; Dieli, F.; Tolomeo, M. Stilbene-based anticancer agents: resveratrol analogues active toward HL60 leukemic cells with a non-specific phase mechanism. Bioorg. Med. Chem. Lett., 2006, 16, 3245-3248.

[126] Fulda, S.; Debatin, K. Sensitization for anticancer drug-induced apoptosis by the chemopreventive agent resveratrol. Oncogene, 2004, 23, 6702-6711.

[127] University of Wisconsin, Madison. A biological study of resveratrol's effects on Notch-1 signaling in subjects with low grade gastrointestinal tumors. In: Clinicaltrials.gov [Internet] 2011. [Cited 2012 Dec. 2] Available from: http://www.clinicaltrials.gov/ ct2/show/NCT01476592?term=resveratrol\&rank $=22 \quad$ NLM Identifier: NCT01476592

[128] University of Michigan Cancer Center; National Cancer Institute. Resveratrol in treating patients with colorectal cancer that can be removed by surgery. In: Clinicaltrials.gov [Internet] 2007. [Cited 2012 Dec. 2] Available from: http://www.clinicaltrials.gov/ct2/ show/NCT00433576?term=resveratrol\&rank=39 NLM Identifier: NCT00433576

[129] University of Michigan Cancer Center; National Cancer Institute. UMCC 2003-064 Resveratrol in preventing cancer in healthy participants (IRB 2004-535). In: Clinicaltrials.gov [Internet] 2004 [Cited 2012 Dec. 2] Available from: http://www.clinicaltrials. gov/ct2/show/NCT00098969?term=resveratrol\&rank=41 NLM Identifier: NCT00098969

[130] Aggarwal, B.B.; Bhardwaj, A.; Aggarwal, R.; Seeram, N.P.; Shishodia, S.; Takada, Y. Role of resveratrol in prevention and therapy of cancer: preclinical and clinical studies. Anticancer Res., 2004, 24, 2783-2840.

[131] Signorelli, P.; Ghidoni, R. Resveratrol as an anticancer nutrient: molecular basis, open questions and promises. J. Nutr. Biochem., 2005, 16, 449-466.

[132] Athar, M.; Back, J.H.; Tang, X.; Kim, K.H.; Kopelovich L.; Bickers, D.R.; Kim, A L. Resveratrol: a review of preclinical studies for human cancer prevention. Toxicol. Appl. Pharmacol., 2007, 224, 274-283.

[133] Remsber, C.M.; Yáñez, J.A.; Ogami, Y.; Vega-Villa, K.R.; Rimando, A.M.; Davies, N.M. Pharmacometrics of pterostilbene: preclinical pharmacokinetics and metabolism, anticancer, antiinflammatory, antioxidant and analgesic activity. Phytother. Res., 2007, 22, 169-179.

[134] Piotrowska, H.; Kucinska, M.; Murias, M. Biological activity of piceatannol: leaving the shadow of resveratrol. Mutat. Res.-Rev. Mutat., 2012, 750, 60-82.

[135] Chowdhury, S.A.; Kishino, K.; Satoh, R.; Hashimoto, K.; Kikuchi, H.; Nishiwaka, H.; Shirataki, Y.; Sakagami, H. Tumor-specificity and apoptosis-inducing activity of stilbenes and flavonoids. Anticancer Res., 2005, 25, 2055-2064.

[136] Lee, E.; Min, H.; Park, H. J.; Chung, H.; Kim, S.; Han, Y.N.; Lee, S.K. G2/M cell cycle arrest and induction of apoptosis by a stilbenoid, 3,4,5-trimethoxy-4V-bromo-cis-stilbene, in human lung cancer cells. Life Sci., 2004, 75, 2829-2839.

[137] Osmond, G.W.; Masko, E.M.; Tyler, D.S.; Freedland, S.J.; Pizzo, S. In vitro and in vivo evaluation of resveratrol and 3,5-dihydroxy4'-acetoxy-trans-stilbene in the treatment of human prostate carcinoma and melanoma. J. Surg. Res., 2013, 179, 141-148.

[138] Košiková, B.; Slameňová, D.; Mikulášová, M.; Horváthová, E.; Lábaj, J. Reduction of carcinogenesis by bio-based lignin derivatives. Biomass Bioenerg., 2002, 23, 153-159.

[139] Thompson, L.U. Experimental studies on lignans and cancer. Bailliere Clin. Endoc., 1998, 12, 691-705.

[140] Park, B.; Oh, S.; Ahn, K.; Kwon, O.; Lee, H. (-)-Syringaresinol inhibits proliferation of human promyelocytic HL-60 leukemia cells via G1 arrest and apoptosis. Int. Immunopharmacol., 2008, 8, 967-973. 
[141] Bylund, A.; Saarinen, N.; Zhang, J.; Bergh, A.; Widmark, A.; Johansson, A.; Lundin, E.; Adlercreutz, H.; Hallmans, G.; Stattin, P.; Mäkela, S. Anticancer effects of a plant lignan 7Hydroxymatairesinol on a prostate cancer. Exp. Biol. Med., 2005, 230, 217-223

[142] Giri, A.; Narasu, M.L. Production of podophyllotoxin from Podophyllum hexandrum: a potential natural product for clinically useful anticancer drugs. Cytotechnology, 2000, 34, 17-26.

[143] Greenwald, R.B.; Conover, C.D.; Pendri, A.; Choe, Y.H.; Martinez, A.; Wu, D.; Guan, S.; Yao, Z.; Shum, K.L. Drug delivery of anticancer agents: water soluble 4-poly (ethylene glycol) derivatives of the lignan, podophyllotoxin. J. Control Release, 1999, 61, 281-294.

[144] Mustafa, J.; Khan, S.I.; Ma, G.; Walker, L.A.; Khan, I.A. Synthesis and anticancer activities of fatty acid analogs of podophyllotoxin. Lipids, 2004, 39, 167-172.

[145] University of Pittsburg; Novartis Pharmaceuticals. Carboplatin and Etoposide plus LBH589 for small cell lung cancer. In: Clinicaltrials.gov [Internet] 2009. [Cited 2012 Dec. 5] Available from: http:/www.clinicaltrials.gov/ct2/show/NCT00958022?term= podophyllotoxin\&rank=6 NLM Identifier: NCT00958022

[146] Northwestern University; National Cancer Institute. Doxorubicin hydrochloride liposome and rituximab with combination chemotherapy in treating patients with newly diagnosed Burkitt's lymphoma or Burkitt-like lymphoma. In: Clinicaltrials.gov [Internet] 2006. [Cited 2012 Dec.5] Available from: http://www. clinicaltrials.gov/ct2/show/NCT00392990?term=podophyllotoxin\& rank=5 NNLM Identifier: NCT00392990

[147] City of Hope Medical Center. Busulfan, Etoposide, and intensitymodulated radiation therapy followed by donor stem cell transplant in treating patients with advanced myeloid cancer. In: Clinicaltrials.gov [Internet] 2007. [Cited 2012 Dec. 5] Available from: http://www.clinicaltrials.gov/ct2/show/NCT00540995?term= podophyllotoxin\&rank=4 NLM Identifier: NCT00540995

[148] Case Comprehensive Cancer Center. Bortezomib, Mitoxantrone, Etoposide, and Cytarabine in relapsed or refractory acute myeloid leukemia. In: Clinicaltrials.gov [Internet] 2010. [Cited 2012 Dec. 5] Available

from: http:/www.clinicaltrials.gov/ct2/show/NCT01127009?term=podop hyllotoxin\&rank=1 NLM Identifier: NCT01127009

[149] Landete, J.M. Plant and mammalian lignans: A review of source, intake, metabolism, intestinal bacteria and health. Food Res. Int., 2012, 46, 410-424.

[150] Wei, Y.; Zhao, X.; Kariya, Y.; Fukata, H.; Teshigawara, K.; Uchida, A. Induction of apoptosis by quercetin: involvement of heat shock protein. Cancer Res., 1994, 54, 4952-4957.

[151] Tan, W.; Lin, L.; Li, M.; Zhang, Y.; Tong, Y.; Xiao, D.; Ding, J. Quercetin, a dietary-derived flavonoid, possesses antiangiogenic potential. Eur. J. Pharmacol., 2003, 459, 255-262.

[152] Nair, H.; Rao, K.V.K.; Aalinkeel, R.; Mahajan, S.; Chawda, R.; Schwartz, S.A. Inhibition of prostate cancer cell colony formation by the flavonoid quercetin correlates with modulation of specific regulatory genes. Clin. Diagn. Lab. Immunol., 2004, 11, 63-69.

[153] Zhang, H.; Zhang, M.; Yu, L.; Zhao, Y.; He, N.; Yang, X. Antitumor activities of quercetin and quercetin-50,8-disulfonate in human colon and breast cancer cell lines. Food Chem. Toxicol., 2012, 50, 1589-1599.

[154] Tan, J.; Wang, B.; Zhu, L. DNA binding and oxidative DNA damage induced by a quercetin copper(II) complex: potential mechanism of its antitumor properties. J. Biol. Inorg. Chem., 2009, $14,727-739$

[155] Tan, J.; Wang, B.; Zhu, L. DNA binding, cytotoxicity, apoptotic inducing activity, and molecular modeling study of quercetin zinc(II) complex. Bioorg. Chem., 2009, 17, 614-620.

[156] Yuan, Z.; Chen, L.; Fan, L.; Tang, M.; Yang, G.; Yang, H.; Du, X.; Wang, G.; Yao, W.; Zhao, Q.; Ye, B.; Wang, R.; Diao, P.; Zhang, W.; Wu, H.; Zhao, X.; Wei, Y. Liposomal quercetin efficiently suppresses growth of solid tumors in murine models. Clin. Cancer Res., 2006, 12, 3193-3199.

[157] Ferry, D.R.; Smith, A.; Malkhandi, J.; Fyfe, D.W.; Takats, P.G.; Anderson, D.; Baker, J.; Kerr, D.J. Phase I clinical trial of the flavonoid quercetin: pharmacokinetics and evidence for in vivo tyrosine kinase inhibitor. Clin. Cancer Res., 1996, 2, 659-668.
[158] Mulholland, P.J.; Ferry, D.R.; Anderson, D.; Hussain, S.A.; Young, A.M.; Cook, J.E.; Hodgkin, E.; Seymour, L.W.; Kerr, D.J. Preclinical and clinical study of QC12, a water-soluble, pro-drug of quercetin. Ann. Oncol., 2001, 12, 245-148.

[159] Mylonis, I.; Lakka, A.; Tsakalof, A.; Simos, G. The dietary flavonoid kaempferol effectively inhibits HIF-1 activity and hepatoma cancer cell viability under hypoxic conditions. Biochem. Biophys. Res. Commun., 2010, 398, 74-78.

[160] Zhang, Y.; Chen, A. Y.; Li, M.; Chen, C.; Yao, Q. Ginkgo biloba extract kaempferol inhibits cell proliferation and induces apoptosis in pancreatic cancer cells. J. Surg. Res., 2008, 148, 17-23.

[161] Yoshida, T.; Konishi, M.; Horinaka, M.; Yasuda, T.; Goda, A.E.; Taniguchi, H.; Yano, K.; Wakada, M.; Sakai, T. Kaempferol sensitizes colon cancer cells to TRAIL-induced apoptosis. Biochem. Biophys. Res. Commun., 2008, 375, 129-133.

[162] Huang, W.; Chiu, Y.; Fan, M.; Lu, H.; Yeh, H.; Li, K.; Chen, P.; Chung, J.; Yang, J. Kaempferol induced apoptosis via endoplasmic reticulum stress and mitochondria-dependent pathway in human osteosarcoma U-2 OS cells. Mol. Nutr. Food Res., 2010, 54, 1585-1595.

[163] Woo, K.J.; Jeong, Y.; Park, J.; Kwon, T. Chrysin-induced apoptosis is mediated through caspase activation and Akt inactivation in U937 leukemia cells. Biochem. Biophys. Res. Commun., 2004, 325, 1215-1222.

[164] Li, X.; Wang, J.; Huang, J.; Xiong, X.; Chen, M.; Ong, C.; Shen, H.; Yang, X. Chrysin promotes tumor necrosis factor (TNF)-related apoptosis-inducing ligand (TRAIL) induced apoptosis in human cancer cell lines. Toxicol. In Vitro, 2011, 25, 630-635.

[165] Khan, M.S.; Devaraj, H.; Devaraj, N. Chrysin abrogates early hepatocarcinogenesis and induces apoptosis in N-nitrosodiethylamineinduced preneoplastic nodules in rats. Toxicol. Appl. Pharmacol., 2011, 251, 85-94.

[166] Glory, M.D.; Thiruvengadam, D. Potential chemopreventive role of chrysin against $\mathrm{N}$-nitrosodiethylamine-induced hepatocellular carcinoma in rats. Biomed. Prev. Nutr., 2012, 2, 106-112.

[167] Drees, M.; Dengler, W.A.; Roth,T.; Labonte, H.; Mayo, J.; Malspeis, L.; Grever, M.; Sausville,E.A.; Fiebig, H.H. Flavopiridol (L86-8275): selective antitumor activity in vitro and activity in vivo for prostate carcinoma cells. Clin. Cancer Res., 1997, 3, 273-279.

[168] Wenzel, U.; Kuntz, S.; Brendel, M.D.; Daniel, H. Dietary flavone is a potent apoptosis inducer in human colon carcinoma cells. Cancer Res., 2000, 60, 3823-3831.

[169] Tundis, R.; Deguin, B.; Loizzo, M.R.; Bonesi, M.; Statti, G.A.; Tillequin, F.; Menichini, F. Potential antitumor agents: flavones and their derivatives from Linaria reflexa Desf. Bioorg. Med. Chem. Lett., 2005, 15, 4757-4760.

[170] Lv, P.; Wang, K.; Li, Q.; Chen, J.; Sun, J.; Zhu, H. Design, synthesis and biological evaluation of chrysin long-chain derivatives as potential anticancer agents. Bioorg. Med. Chem., 2010, 18, 1117-1123.

[171] Corbett, T.H.; Bissery, M.; Wozniak, A.; Plowman, J.; Polin, L.; Tapazoglou, E.; Dieckman, J.; Valeriote, F. Activity of flavone acetic acid (NSC-347512) against solid tumors of mice. Invest. New Drugs, 1986, 4, 207-220.

[172] Evelhoch, J.L.; Bissery, M.; Chabot, G.G.; Simpson, N.E.; McCoy, C.L.; Heilbrun, L.K.; Corbett, T.H. Flavone acetic acid (NSC 347512)-induced modulation of murine tumor physiology monitored by in vivo nuclear magnetic resonance spectroscopy. Cancer Res., 1988, 48, 4749-4755.

[173] Kerr, D.J.; Maughan, T.; Newlands, E.; Rustin, G.; Bleehen, N.M.; Lewis, C.; Kaye, S.B. Phase II trials of flavone acetic acid in advanced malignant melanoma and colorectal carcinoma. Br. J. Cancer, 1989, 60, 104-106.

[174] Bibby, M.C. Flavone acetic acid - an interesting novel therapeutic agent or just another disappointment? Br. J. Cancer, 1991, 63, 3-5.

[175] Kitson, R.P.; Ohashi, M.; Brunson, K.W.; Goldfarb, R.H. Flavone acetic acid enhances accumulation of IL-2 activated NK cells within established metastases. In Vivo, 1998, 6, 593-597.

[176] Panaro, N.J.; Popescu, N.C.; Harris, S.R.; Thorgeirsson, U.P. Flavone acetic acid induces a G2/M cell cycle arrest in mammary carcinoma cells. Br. J. Cancer, 1999, 80, 1905-1911.

[177] Joshi, K.S.; Rathos, M.J.; Mahajan, P.; Wagh, V.; Shenoy, S.; Bhatia, D.; Chile, S.; Sivakumar, M.; Maier, A.; Fiebig, H.; 
Sharma, S. P276-00, a novel cyclin-dependent inhibitor induces G1-G2 arrest, shows antitumor activity on cisplatin-resistant cells and significant in vivo efficacy in tumor models. Mol. Cancer Ther., 2007, 6, 926-934.

[178] Piramal Healthcare Limited. A clinical trial comparing Gemcitabine and Carboplatin with and without P276-00 in subjects with metastatic triple negative breast cancer, with a run-in of escalating dose of P276-00 added to Gemcitabine and Carboplatin. In: Clinicaltrials.gov [Internet] 2011. [Cited 2012 Oct. 23] Available from: http://clinicaltrials.gov/ct2/show/record/NCT01333137?term= flavone\&rank=1 NLM Identifier: NCT01333137

[179] Menon, L.G.; Kuttan, R.; Kuttan, G. Anti-metastatic activity of curcumin and catechin. Cancer Lett., 1999, 141, 159-165.

[180] Al-Hazzani, A.; Alshatwi, A.A. Catechin hydrate inhibits proliferation and mediates apoptosis of $\mathrm{SiHa}$ human cervical cancer cells. Food Chem. Toxicol., 2011, 49, 3281-3286.

[181] Farivar-Mohseni, H.; Kandzari, S.J.; Zaslau, S.; Riggs, D.R.; Jackson, B.J.; McFadden, D.W. Synergistic effects of Cox-1 and -2 inhibition on bladder and prostate cancer in vitro. Am. J. Surg., 2004, 188, 505-510

[182] McMillian, B.; Riggs, D.R.; Jackson, B.J.; Cunningham, C.; McFadden, D.W. Dietary influence on pancreatic cancer growth by catechin and inositol hexaphosphate. J. Surg. Res., 2007, 141, 115119.

[183] Vittorio, O.; Cirillo, G.; Iemma, F.; Di Turi, G.; Jacchetti, E.; Curcio, M.; Barbuti, S.; Funel, N.; Parisi, O.I.; Picci, N. Dextrancatechin conjugate: a potential treatment against the pancreatic ductal adenocarcinoma. Pharm. Res., 2012, 29, 2601-2614.

[184] University of Arizona; National Cancer Institute. Green tea extract (Polyphenon E) in preventing cancer in healthy participants. In: Clinicaltrials.gov [Internet] 2004. [Cited 2012 Oct. 25] Available from: http://clinicaltrials.gov/ct2/show/NCT00091325?term=catechin\& rank=33 NLM Identifier: NCT00091325

[185] National Cancer Institute; University of Arizona. Green tea extract in preventing cervical cancer in patients with human papillomavirus and low-grade cervical intraepithelial neoplasia. In: Clinicaltrials.gov [Internet] 2006. [Cited 2012 Oct. 25] Available from:

http://clinicaltrials.gov/ct2/show/NCT00303823?term=catechin\&ra nk=32 NLM Identifier: NCT00303823

[186] M.D. Anderson Cancer Center; National Cancer Institute. Green tea extract in preventing esophageal cancer in patients with Barrett's esophagus. In: Clinicaltrials.gov [Internet] 2005. [Cited 2012 Oct. 25] Available from: http://clinicaltrials.gov/ct2/show/ NCT00233935?term=catechin\&rank=39 NLM Identifier: NCT00233935

[187] University of Wisconsin, Madison; National Cancer Institute. Green tea extract in treating patients with nonmetastatic bladder cancer. In: Clinicaltrials.gov [Internet] 2008. [Cited 2012 Oct. 25] Available from: http://clinicaltrials.gov/ct2/show/NCT00666562? term $=$ catechin\&rank=22 NLM Identifier: NCT00666562

[188] National Cancer Institute; Univeristy of Arizona. Defined green tea catechins in treating patients with prostate cancer undergoing surgery to remove the prostate. In: Clinicaltrials.gov [Internet] 2008. [Cited 2012 Oct. 25] Available from: http://clinicaltrials. gov/ct2/show/record/NCT00459407?term=catechin\&rank=14 NLM Identifier: NCT00459407

[189] Case Comprehensive Cancer Center; National Cancer Institute. Defined green tea catechin extract in treating patients with localized prostate cancer undergoing surgery. In: Clinicaltrials.gov [Internet] 2011. [Cited 2012 Oct. 25] Available from: http://clinicaltrials.gov/ct2/show/record/NCT01340599?term=catec hin\&rank=5 NLM Identifier: NCT01340599

[190] Mayo Clinic; National Cancer Institute. Polyphenon E in treating patients with high-risk of colorectal cancer. In: Clinicaltrials.gov [Internet] 2012. [Cited 2012 Oct. 25] Available from: http://clinicaltrials.gov/ct2/show/NCT01606124?term=catechin\&ra nk=23 NLM Identifier: NCT01606124

[191] Lung, H.L.; Ip, W.K.; Wong, C.K.; Mak, N.K.; Chen, Z.Y.; Leung, K.N. Anti-proliferative and differentiation-inducing activities of the green tea catechin epigallocatechin-3-gallate (EGCG) on the human eosinophilic leukemia EoL-1 cell line. Life Sci., 2002, 72, 257-268.
[192] Magyar, J. É.; Gamberucci, A.; Konta, L.; Margittai, É.; Mandl, J.; Bánhehyi G.; Benedetti, A.; Csala, M. Endoplasmic reticulum stress underlying the pro-apoptotic effect of epigallocatechin gallate in mouse hepatoma cells. Int. J. Biochem. Cell Biol., 2009, 41, 694-700

[193] Ellis, L.Z.; Liu, W.; Luo, Y.; Okamoto, M.; Qu, D.; Dunn, J.H.; Fujita, M. Green tea polyphenol epigallocatechin-3-gallate suppresses melanoma growth by inhibiting inflammasome and IL$1 \beta$ secretion. Biochem. Biophys. Res. Commun., 2011, 414, 551556.

[194] Matsumura, K.; Kaihatsu, K.; Mori, S.; Cho, H.H.; Kato, N.; Hyon, S.H. Enhanced antitumor activities of (-)-epigallocatechin-3-Ogallate fatty acid monoester derivatives in vitro and in vivo. Biochem. Biophys. Res. Commun., 2008, 377, 1118-1122.

[195] Singh, B.N.; Shankar, S.; Srivastava, R.K. Green tea catechin, epigallocatechin-3-gallate (EGCG): Mechanisms, perspectives and clinical applications. Biochem. Pharmacol., 2011, 82, 1807-1821.

[196] Martin-Luther-Universität Halle-Wittenberg; University of Ulm; Koordinierungszentrum für Klinische Studien Halle; Deutsche Krebshilfe e.V., Bonn (Germany). Minimizing the risk of metachronous adenomas of the colorectum with green tea extract MIRACLE-. In: Clinicaltrials.gov [Internet] 2011. [Cited 2012 Oct. 25] Available from: http://clinicaltrials.gov/ct2/show/NCT01360320? term=epigallocatechin\&rank=17 NLM Identifier: NCT01360320

[197] University of Minnesota - Clinical and Translational Science Institute Green tea and reduction of breast cancer risk. In: Clinicaltrials.gov [Internet] 2009. [Cited 2012 Oct. 25] Available from: http:// clinicaltrials.gov/ct2/show/NCT00917735?term=epigallocatechin\& rank=24 NML Identifier: NCT00917735

[198] Shandong Cancer Hospital and Institute. Oral green tea extract for small cell lung cancer. In: Clinicaltrials.gov [Internet] 2011. [Cited 2012 Oct. 25] Available from: http://clinicaltrials.gov/ct2/show/ NCT01317953?term=epigallocatechin\&rank=13 NML Identifier: NCT01317953

[199] Suzuki, K.; Koike, H.; Matsui, H.; Ono, Y.; Hasumi, M.; Nakazato, H.; Okugi, H.; Sekine, Y.; Oki, K.; Ito, K.; Yamamoto, T.; Fukabori, Y.; Kurokawa, K.; Yamanaka, H. Genistein, a soy isoflavone, induces glutathione peroxidase in the human prostate cancer cell lines LNCAP and PC-3. Int. J. Cancer, 2002, 99, 846852.

[200] Wang, J.; Eltoum, I.; Lamartiniere, C.A. Dietary genistein suppresses chemically induced prostate cancer in Lobund-Wistar rats. Cancer Lett., 2002, 186, 11-18.

[201] Banerjee, S.; Zhang, Y.; Ali, S.; Bhuiyan, M.; Wang, Z.; Chiao, P.J.; Philip, P.A.; Abbruzzese, J.; Sarkar, F.H. Molecular evidence for increased antitumor activity of gemcitabine by genistein in vitro and in vivo using an orthotopic model of pancreatic cancer. Cancer Res., 2005, 65, 9064-9072.

[202] Mohammad, R.M.; Banerjee, S.; Li, Y.; Aboukameel, A.; Kucuk, O.; Sarkar, F.H. Cisplatin-induced antitumor activity is potentiated by the soy isoflavone genistein in BxPC-3 pancreatic tumor xenografts. Cancer, 2006, 106, 1260-1268.

[203] Yanhong, H.; Peng, Y.; Qinghong, Z.; Xiaoyan, X. Genistein sensitizes ovarian carcinoma cells to chemotherapy by switching the cell cycle progression in vitro. J. Med. Coll. PLA, 2009, 24, $125-135$.

[204] Sahin, K.; Tuzcu, M.; Basak, N.; Caglayan, B.; Kilic, U.; Sahin, F.; Kucuk, O. Sensitization of cervical cancer cells to cisplatin by genistein: the role of $\mathrm{NF \kappa B}$ and $\mathrm{Akt} / \mathrm{mTOR}$ signaling pathways. $J$. Oncol., 2012, 2012, 1-6.

[205] Siegelin, M.D.; Siegelin, Y.; Habel, A.; Gaiser, T. Genistein enhances proteasomal degradation of the short isoform of FLIP in malignant glioma cells and thereby augments TRAIL-mediated apoptosis. Neurosci. Lett., 2009, 453, 92-97.

[206] Banerjee, S.; Li, Y.; Wang, Z.; Sarkar, F.H. Multi-targeted therapy of cancer by genistein. Cancer Lett., 2008, 269, 226-242.

[207] Perabo, F.G.E.; Löw, E.C.V.; Rücker, A. V.; Müller, S.C.; Bastian, P.J. Soy isoflavone genistein in prevention and treatment of prostate cancer. Prostate Cancer P.D., 2008, 11, 6-12.

[208] Li, W.; Frame, L.T.; Hirsh, S.; Cobos, E. Genistein and hematological malignancies. Cancer Lett., 2010, 296, 1-8.

[209] Barbara Ann Karmanos Cancer Institute; National Cancer Institute. Gemcitabine hydrochloride and genistein in treating women with stage IV breast cancer. In: Clinicaltrials.gov [Internet] 2005. 
[Cited 2012 Oct. 30] Available from: http://clinicaltrials.gov/ct2/ show/NCT00244933?term=genistein\&rank=11 NML Identifier: NCT00244933

[210] University of Wisconsin, Madison; National Cancer Institute. Genistein in patients who are undergoing surgery for bladder cancer. In: Clinicaltrials.gov [Internet] 2005. [Cited 2012 Oct. 30] Available from: http://clinicaltrials.gov/ct2/show/NCT00118040? term=genistein\&rank=17 NML Identifier: NCT00118040

[211] National Cancer Institute; National Institutes of Health Clinical Center. A pharmacokinetic study of genistein, a tyrosine kinase inhibitor. In: Clinicaltrials.gov [Internet] 1999. [Cited 2012 Oct. 30] Available from: http://clinicaltrials.gov/ct2/show/NCT00001696? term=genistein\&rank=21 NML Identifier: NCT00001696

[212] UNC Lineberger Comprehensive Cancer Center; National Cancer Institute. Genistein in preventing breast or endometrial cancer in healthy postmenopausal women. In: Clinicaltrials.gov [Internet] 2004. [Cited 2012 Oct. 30] Available from: http://clinicaltrials. gov/ct2/show/NCT00099008?term $=$ genistein\&rank $=25 \quad$ NML Identifier: NCT00099008

[213] Barbara Ann Karmanos Cancer Institute; National Cancer Institute. Genistein, Gemcitabine, and Erlotinib in treating patients with locally advanced or metastatic pancreatic cancer. In: Clinicaltrials. gov [Internet] 2006. [Cited 2012 Oct. 30] Available from: $\mathrm{http} / / /$ clinicaltrials.gov/ct2/show/NCT00376948?term=genistein\&r ank=26 NML Identifier: NCT003769

[214] Northwestern University, National Cancer Institute. Genistein in treating patients with prostate cancer. In: Clinicaltrials.gov [Internet] 2010. [Cited 2012 Oct. 30] Available from: http://clinicaltrials. gov/ct2/show/NCT01126879?term=genistein\&rank=1 NML Identifier: NCT01126879

[215] University of Hohenheim; Institute of Nutritional Medicine; University Hospital Tübingen; Quercegen Pharmaceuticals LLC. Prostate cancer prevention trial with quercetin and genistein (QUERGEN). In: Clinicaltrials.gov [Internet] 2012. [Cited 2012 Oct. 30] Available from: http://clinicaltrials.gov/ct2/show/NCT01538316? term=genistein\&rank=2 NML Identifier: NCT01538316

[216] Emory University. Study of genistein in reducing side effects of superficial bladder cancer treatment. In: Clinicaltrials.gov [Internet] 2011. [Cited 2012 Oct. 30] Available from: http://clinicaltrials.gov/ ct2/show/NCT01489813?term=genistein\&rank=7 NML Identifier: NCT01489813

[217] Uman Pharma; DSM Nutritional Products, Inc.; MDEIE Ministry, Québec Government INRS-Institut Armand Frappier; Université du Québec. MTD determination, safety and efficacy of the decitabinegenistein drug combination in advanced solid tumors and nonsmall cell lung cancer. In: Clinicaltrials.gov [Internet] 2012. [Cited 2012 Oct. 30] Available from: http://clinicaltrials.gov/ ct2/show/NCT01628471?term=genistein\&rank=12 NML Identifier: NCT01628471

[218] Northwestern University; National Cancer Institute. Genistein and Interleukin-2 in Treating Patients With Metastatic Melanoma or Kidney Cancer. In: Clinicaltrials.gov [Internet] 2006. [Cited 2012 Oct. 30] Available from: http://clinicaltrials.gov/ct2/show/ NCT00276835?term=genistein\&rank=13 NML Identifier: NCT00276835

[219] Choi E.J.; Kim, G. Daidzein causes cell cycle arrest at the G1 and G2/M phases in human breast cancer MCF-7 and MDA-MB-453 cells. Phytomedicine, 2008, 15, 683-690.

[220] Rabiau, N.; Kossaï, M.; Braud, M.; Chalabi, M.; Satih, S.; Bignon Y.; Bernard-Gallon, D.J. Genistein and daidzein act on a panel of genes implicated in cell cycle and angiogenesis by polymerase chain reaction arrays in human prostate cancer cell lines. Cancer Epidem., 2010, 34, 200-206.

[221] Guo, J.M.; Xiao, B.X.; Liu, D.H.; Grant, M.; Zhang, S.; Lai, Y.F.; Guo, Y.B.; Liu, Q. Biphasic effect of daidzein on cell growth of human colon cancer cells. Food Chem. Toxicol., 2004, 42, 16411646.

[222] Liu, X.; Suzuki, N.; Laxmi, Y.R.S.; Okamoto, Y.; Shibutani, S. Anti-breast cancer potential of daidzein in rodents. Life Sci., 2012, 91, 415-419.

[223] Constantinou, A.I.; White, B.E.P.; Tonetti, D.; Yang, Y.; Liang, W.; Li, W.; Breemen, R.B. The soy isoflavone daidzein improves the capacity of tamoxifen to prevent mammary tumours. Eur. J. Cancer, 2005, 41, 647-654.
[224] Itoigawa, M.; Ito, C.; Ju-ichi, M.; Nobokuni, T.; Ichiishi, E.; Tokuda, H.; Nishino, H.; Furukawa, H. Cancer chemopreventive activity of flavanones on Epstein-Barr virus activation and two-stage mouse skin carcinogenesis. Cancer Lett., 2002, 176, 25-29.

[225] Akihisa, T.; Tokuda, H.; Ukiya, M.; Iizuka, M.; Schneider, S.; Ogasawara, K.; Mukainaka, T.; Iwatsuki, K.; Suzuki, T.; Nishino, H. Chalcones, coumarins, and flavanones from the exudate of Angelica keiskei and their chemopreventive effects. Cancer Lett., 2003, 201, 133-137.

[226] Li, S.; Luo, X.; Li, S.; Dong, M.; Xiong, L. Effect of hesperidin extraction on cell proliferation and apoptosis of CNE-2Z cells. $3 r d$ International Conference on Biomedical Engineering and Informatics, 2010, 2024-2027.

[227] Natarajan, N.; Thamaraiselvan, R.; Lingaiah, H.; Srinivasan, P.; Periyasamy, B.M. Effect of flavonone hesperidin on the apoptosis of human mammary carcinoma cell line MCF-7. Biomed. Preven. Nutr., 2011, 1, 207-215.

[228] Shen, S.; Ko, C.H.; Tseng, S.; Tsai, S.; Chen, Y. Structurally related antitumor effects of flavanones in vitro and in vivo: involvement of caspase 3 activation, p21 gene expression, and reactive oxygen species production. Toxicol. Appl. Pharmacol., 2004, 197, 84-95.

[229] Hsiao, Y.; Hsieh, Y.; Kuo, W.; Chiou, H.; Yang, S.; Chinag, W.; $\mathrm{Chu}, \mathrm{S}$. The tumor-growth inhibitory activity of flavanone and $2 \phi-$ $\mathrm{OH}$ flavanone in vitro and in vivo through induction of cell cycle arrest and suppression of cyclins and CDKs. J. Biomed. Sci., 2007, $14,107-119$.

[230] Hafeez, B.B.; Siddiqui, I.A.; Asim, M.; Malik, A.; Afaq, F.; Adhami, V.M.; Saleem, M.; Din, M.; Mukhtar, H. A dietary anthocyanidin delphinidin induces apoptosis of human prostate cancer PC3 cells in vitro and in vivo: involvement of nuclear factor-KB signaling. Cancer Res., 2008, 68, 8564-8572.

[231] Hou, D.; Tong, X.; Terahara, N.; Luo, D.; Fujii, M. Delphinidin 3sambubioside, a Hibiscus anthocyanin, induces apoptosis in human leukemia cells through reactive oxygen species-mediated mitochondrial pathway. Arch. Biochem. Biophys., 2005, 440, 101109.

[232] Chen, P.; Chu, S.; Chiou, H.; Kuo, W.; Chinag, C.; Hsieh, Y. Mulberry anthocyanins, cyanidin 3-rutinoside and cyanidin 3glucoside, exhibited an inhibitory effect on the migration and invasion of a human lung cancer cell line. Cancer Lett., 2006, 235, 248-259.

[233] Qian, X.; Li, J.; Ding, J.; Wang, Z.; Duan, L.; Hu, G Glibenclamide exerts an antitumor activity through reactive oxygen species-c-jun $\mathrm{NH}(2)$-terminal kinase pathway in human gastric cancer cell line MGC-803. Biochem. Pharmacol., 2008, 76, 17051715 .

[234] Sun, C.; Zheng, Y.; Chen, Q.; Tang, X.; Jiang, M.; Zhang, J.; Li, $\mathrm{X}$.; Chen, K. Purification and antitumour activity of cyanidin-3-Oglucoside from Chinese bayberry fruit. Food Chem., 2012, 131, $1287-1294$

[235] Cvorovic, J.; Tramer, F.; Granzotto, M.; Candussio, L.; Decorti, G.; Passamonti, S. Oxidative stress-based cytotoxicity of delphinidin and cyanidin in colon cancer cells. Arch. Biochem. Biophys., 2010, 501, 151-157.

[236] Ho, M.; Chen, P.; Chu, S.; Kuo, D.; Kuo, W.; Chen J.; Hsieh, Y. Peonidin 3-glucoside inhibits lung cancer metastasis by downregulation of proteinases activities and MAPK pathway. Nutr. Cancer, 2010, 62, 505-516.

[237] Ding, M.; Feng, R.; Wang, S. Y.; Bowman, L.; Lu, Y.; Qian, Y.; Castranova, V.; Jiang, B.; Shi, X. Cyanidin-3-glucoside, a natural product derived from blackberry, exhibits chemopreventive and chemotherapeutic activity. J. Biol. Chem., 2006, 281, 17359-17368.

[238] Littleton, J.; Rogers, T.; Falcone, D. Novel approaches to plant drug discovery based on high throughput pharmacological screening and genetic manipulation. Life Sci., 2005, 78, 467-475.

[239] Halliwell, B. Free radicals and antioxidants - quo vadis? Trends Pharmacol. Sci., 2011, 32, 125-130.

[240] Hollingshead, M.G. Antitumor Efficacy Testing in Rodents. $J$. Natl. Cancer Inst., 2008, 100, 1500-1510.

[241] Pan, L.; Chai, H.; Kinghorn, D. The continuing search for antitumor agents from higher plants. Phytochem. Lett., 2010, 3, 1-8. 
[242] Ferreira, I.C.F.R.; Vaz, J.A.; Vasconcelos, M.H.; Martins, A. Compounds from wild mushrooms with antitumor potential. AntiCancer Agents Med. Chem., 2010, 10, 424-436.

Received: December 09, 2012
Accepted: June 09, 2013
Revised: February 07, 2013
[243] Boopathy, N.S.; Kathiresan, K. Anticancer drugs from marine flora: an overview. J. Oncol., 2010, 1-18. 